\title{
Struktura i koncentracja przestrzenna siedzib ważniejszych przedsiębiorstw w Warszawie w 1999 r. ${ }^{1}$
}

\section{Wstęp}

Wybór miejsca zarządzania przedsiębiorstwem oprócz uwarunkowań logistycznych, ma duże znaczenie prestiżowe. Poprzez koncentrację siedzib przedsiębiorstw powstaje przestrzeń zarządzania, będąca istotnym składnikiem i czynnikiem kształtującym rozwój centrum miasta. Badania lokalizacji przedsiębiorstw mają zatem istotne znaczenie m.in. z punktu widzenia delimitacji obszarów centralnych.

Badania lokalizacji siedzib w skali wewnątrzmiejskiej w Polsce dotychczas były prowadzone w dość ograniczonym zakresie. Sytuacja ta miała podłoże w uwarunkowaniach związanych z ustrojem centralnego planowania, w której pierwszorzędne znaczenie odgrywało istnienie i położenie ośrodków i obiektów władzy polityczno-administracyjnej, determinujące funkcje zarządzające gospodarką i przedsiębiorstwami. Zagadnienie funkcji zarządzającej miast, także w skali wewnątrzmiejskiej, doczekało się zatem dość bogatej literatury w odniesieniu do administracji państwowej, m.in. głównie tej problematyce poświęcone było jedno z łódzkich Konwersatoriów Wiedzy o Mieście (Funkcja administracyjna miast, 1992). W poszczególnych referatach wprawdzie przewijały się w różnym stopniu zagadnienia lokalizacji siedzib przedsiębiorstw (najszczegółowiej u S. Liszewskiego i A. Wolaniuk, 1992), ale w tym znaczeniu funkcja gospodarcza w opracowaniach odgrywała zazwyczaj wtórną rolę.

Problematyka lokalizacji głównych siedzib przedsiębiorstw wystąpiła przy okazji badań nad strukturą i powiązaniami regionalnymi ośrodków miejskich w skali ponadmiejskiej (m.in. Eberhardt, Wróbel 1963, Eberhardt 1968, Eberhardt 1970, Owczarek 1983, Eberhardt 1987). W ostatnim opracowaniu dowiedziono, że oprócz Warszawy jest w Polsce zaledwie jeszcze 7 miast, których znaczenie regionalne jako ośrodków zarządzania jest istotne: Kraków, Wrocław, Katowice, Łódź, Poznań, Szczecin i Gdańsk. Wszystkie analizy zakładały dominację Warszawy jako ośrodka centralnego dla siedzib przedsiębiorstw lub też analizowały zależności regionalne położenia siedzib oddziałów terenowych, nie kwe-

\footnotetext{
'Artykuł jest rozszerzoną wersją opracowania, zamieszczonego w materiałach XIV Konwersatorium Wiedzy o Mieście w Lodzi (Śleszyński 2001b). Materiały prezentowano także podczas 50. Zjazdu PTG w Polańczyku (Śleszyński 2001c). W opracowaniu wykorzystano wyniki badań prowadzonych w ramach grantu KBN nr 6PO4E 02I 19 pt. „Transformacja przestrzeni miejskiej Warszawy w latach 1990-99 na przykładzie zachodniej części centrum”.
} 
stionując stołecznego umiejscowienia centrali. Zagadnienie rozmieszczenia głównych siedzib przedsiębiorstw $\mathrm{i}$ ich filii było natomiast znacznie częściej badane w geografii przemysłu. Na przykład S. Misztal (1998) podaje, że w końcu 1975 r. poza granicami Warszawy na Mazowszu działało 286 zakładów-filii podlegających organizacyjnie stołecznym przedsiębiorstwom przemysłowym, zatrudniających około 38 tys. osób, a dalsze 25 tys. osób pracowało w oddziałach w pozostałej części kraju.

W ostatnich latach studia w skali ogólnokrajowej podjęli B. Wyżnikiewicz (1997), R. Guzik i K. Gwosdz (2000), E. Nowosielska (2001) oraz P. Śleszyński (2002a). W badaniach wykazano, że funkcja kontrolna w polskiej gospodarce, oprócz nadal silnej koncentracji zarządzania w Warszawie, wykazuje zróżnicowanie regionalne (np. różny udział kapitału zagranicznego). W opracowaniu J. Wendta (2001) przedstawiono strukturę przestrzenną ośrodków władzy w Polsce. Ponadto w skali globalnej Z. Zioło (2001) omówił problematykę struktury branżowej i koncentracji przestrzennej wiodących firm światowych, zaś M. Śleszyńska i P. Śleszyński (2001) opracowali mapy rozmieszczenia siedzib największych firm i korporacji międzynarodowych oraz banków. Ogólnie, podjęcie szerszych badań nad geografią przedsiębiorstw jest w ostatnich latach mocno postulowane (m.in. Domański 1997) i należy się wkrótce spodziewać większej ilości opracowań na ten temat.

W gospodarce rynkowej umiejscowienie siedzib przedsiębiorstw (ang. headquarters) ma istotne znaczenie. Wyróżnić tutaj można następujące role wynikające z istnienia siedziby (siedzib) w danej miejscowości (Śleszyński 2002a):

- rola gospodarcza, najbardziej złożona, która polega przede wszystkim na różnym udziale w tworzeniu miejscowego PKB i odprowadzaniu podatków, w zależności od posiadania (lub nie) oddziałów zamiejscowych, filii, itp. Posiadanie oddziałów zamiejscowych jest charakterystyczne m.in. dla dużych przedsiębiorstw sektora usługowego. Można przyjąć uogólnienie, że umiejscowienie centrali przedsiębiorstwa wiąże się przede wszystkim z rodzajem działalności: im bardziej zaawansowany dział gospodarki, tym lokalizacja głównej siedziby wiąże się z wyższymi stopniami hierarchii administracyjnej, przy na ogół jednoczesnej dużej liczbie oddziałów zamiejscowych. Rolą gospodarczą jest także udział $w$ inwestycjach oraz efekt mnożnikowy, polegający w tym przypadku na tendencji do koncentracji działalności w regionie oddziaływania siedziby dużego przedsiębiorstwa (m.in. obsługa finansowa, prawna i logistyczna, doradztwo gospodarcze, itp.);

- rola społeczna, w której można wydzielić dwie grupy zagadnień: wynikającą z aspektów gospodarczych (np. wpływ na stopę bezrobocia, przyciąganie wysokokwalifikowanej kadry) oraz polegającą na kreowaniu wizerunku poprzez podnoszenie prestiżu miejscowości i regionu;

- rola polityczna, konsekwencją której jest często udział przedstawicieli biznesu we władzach lokalnych i tym samym realny wpływ przedsiębiorstwa na administrację lokalną i zarządzanie regionem.

Z powyższych względów zagadnienie lokalizacji głównych siedzib przedsiębiorstw w krajach o ugruntowanej gospodarce rynkowej rozpoznawane jest od dość dawna, głównie przez geografów ekonomicznych i ekonomistów. Do pionierskich należą m.in. opracowania R.B. McNee'a (1958, 1960), gdzie użyto określenia ,geografia przedsiębiorstwa” (geography of enterprise). Już W. Godwin (1965) zauważył, że funkcja kontrolna (control function) jest szczególnie istotna dla procesów alokacyjnych w systemach ekonomiczno- 
-geograficznych i z tego względu powinna być przedmiotem wnikliwych badań. Jednak szczególnie żywe zainteresowanie tematyką głównych siedzib przedsiębiorstw i organizacji notuje się począwszy od lat 70. (m.in. Borchert 1978, Burns 1977, Dicken 1977, Dicken, Lloyd 1978, Evans 1973, Fujita 1987, Godard, Smith 1978, Hayter, Watts 1984, Hino 1995, Holloway, Wheeler 1991, Malecki 1979, Pred 1974, Pred 1977, Rees 1978, Semple 1973, Semple 1985, Semple, Phipps 1982, Sheppard, Maier, Tödtling 1990, Taylor, Thrift 1981, Westaway 1974, Wheeler 1986. Wheeler, Park 1984, Zeller 2000). Cytowani autorzy zwracali uwagę m.in. na fakt, że lokalizacja siedzib przedsiębiorstw związana jest przede wszystkim z dużymi aglomeracjami ze względu na dostęp do administracji i urzędów, łatwość komunikowania się ze „światem" (transport, łączność), istnienie specjalistycznej obsługi (kancelarie prawne, banki, doradztwo gospodarcze, itd.), a także łatwiejsze pozyskiwanie kadry zarządzającej.

Lokalizacja głównej siedziby przedsiębiorstwa i miejsca jego rzeczywistej działalności nie zawsze się pokrywają. Ma to miejsce przede wszystkim w przypadku przedsiębiorstw, które posiadają liczne filie. Najogólniej, dotyczy to przede wszystkim przedsiębiorstw branży finansowej (bankowość, ubezpieczenia) i handlowo-usługowej, zaś w nieco mniejszym stopniu produkcyjnej (Śleszyński 2002a). Rozmieszczenie siedzib przedsiębiorstw nie mówi zatem o rzeczywistym rozmieszczeniu sił wytwórczych, a jedynie o rozmieszczeniu ośrodków decyzyjnych, czyli funkcji kontrolnej (ang. control function). Tym samym można mówić o rozmieszczeniu omawianych siedzib w kontekście „przestrzeni zarządzania". Dlatego też - ze względu na specyfikę zagadnienia, klasyczne teorie i koncepcje lokalizacji mają tutaj ograniczone zastosowanie, a w przypadku ich zastosowania do wyjaśniania przestrzennych i regionalnych zjawisk i procesów decyzyjnych muszą być znacznie modyfikowane.

Zagadnienie rozmieszczenia głównych siedzib przedsiębiorstw w skali wewnątrzmiejskiej było rozpatrywane nieco rzadziej i służyło głównie do wyznaczenia, opisu i wyjaśnienia zjawisk i procesów zachodzących w obrębie centrum funkcjonalnego miasta i aglomeracji (city, CBD - Central Business District). Rozmieszczeniem siedzib przedsiębiorstw w skali wewnątrzmiejskiej zajmowali się w ostatnich 20. latach m.in. Y. Kato i T. Yamazaki (1981), J.O. Wheeler (1988) oraz A. Chiba (1992). W pierwszym cytowanym badaniu, gdzie badano rozwój $C B D$ aglomeracji Kobe stwierdzono m.in., że w ostatnich analizowanych 20 latach nastapilo pewne rozproszenie siedzib przedsiębiorstw. W ostatnim czasie analiza rozmieszczenia siedzib ważniejszych przedsiębiorstw okazała się bardzo pomocna przy wyznaczeniu centrum Warszawy (Śleszyński 2002b).

Celem pracy jest analiza przestrzennego zróżnicowania rozmieszczenia siedzib przedsiębiorstw w Warszawie w 1999 r. na tle obecnej struktury funkcjonalno-przestrzennej. Tym samym badanie ma istotny aspekt praktyczny, gdyż pozwala na porównanie ksztaltującej się po 1989 r. struktury ośrodków decyzyjnych na tle obecnego podziału administracyjnego oraz opracowań urbanistyczno-planistycznych. Badania prowadzono $w$ dezagregacji głównie na sekcje EKD (Europejskiej Klasyfikacji Działalności) oraz strukturę wielkościową i własnościową.

Badania przeprowadzono $w$ dezagregacji na różne obszary: prawo- $i$ lewobrzeżną część Warszawy, poszczególne gminy i dzielnice, wybrane rejony urbanistyczne, w których obserwowano koncentrację głównych siedzib przedsiębiorstw (Ryc. 1) oraz sieć kwadratów o boku $1 \mathrm{~km}$. Tak duże zróżnicowanie poszczególnych powierzchni badawczych umożli- 
wiło uchwycenie prawidłowości w koncentracji siedzib firm oraz ma duży wymiar praktyczny.

Ogółem na terenie Warszawy zlokalizowano główne siedziby 1343 firm, których obroty handlowe w $1999 \mathrm{r}$. wynosiły ponad $10 \mathrm{mln} \mathrm{z}$.
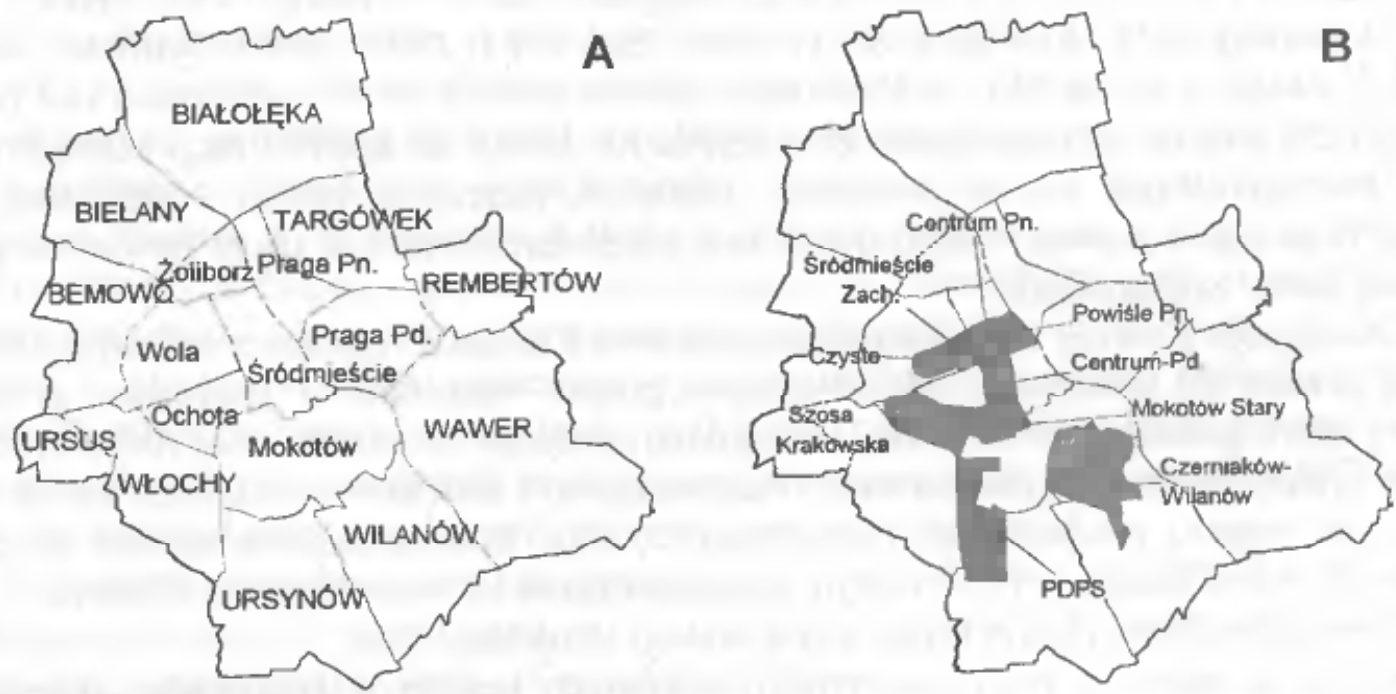

Ryc. 1. Podziały używane w tekście

A - podział administracyjny Warszawy w 1999 r.: BIELANY - gminy Warszawy, Wola - dzielnice gminy Warszawa-Centrum B - wybrane rejony urbanistyczne skróty: Pn. - Północ. Pd. - Południe, Zach. - Zachód, PDPS - Południowa Dzielnica Przemysłowo-Składowa (w części północnej Służewiec Południowy)

\section{Prawidlowości w rozmieszczeniu siedzib przedsiębiorstw}

Rozmieszczenie siedzib przedsiębiorstw wykazuje koncentrację przede wszystkim na obszarze centrum Warszawy (Ryc. 2, Tabela 1). Spośród 1343 siedzib przedsiębiorstw w gminie Warszawa-Centrum zlokalizowanych było 941 (70,1\%), z czego 821 w lewobrzeżnej części. W dzielnicy Śródmieście było 296 siedzib (22,0\%), na Mokotowie - 209 $(15,6 \%)$, a na Woli - 191 (14,2\%). Spośród rejonów urbanistycznych rekordowy pod względem liczby przedsiębiorstw było Centrum Południe (113 siedzib). znajdowały się tu siedziby m.in. takich firm, jak Bank Handlowy, Animex, Prokom Software, Polskie Górnictwo Naftowe i Gazownictwo, Raiffeisen Bank Polska, Budimex. Drugim rejonem koncentracji siedzib przedsiębiorstw była Południowa Dzielnica Przemysłowo-Składowa (Służewiec Południowy), gdzie zlokalizowano siedziby 100 przedsiębiorstw, m.in. Real Polska, Unilever Polska, Henkel, Renault Polska. Inne rejony urbanistyczne o dużej koncentracji siedzib to także Centrum Północ (88), Sródmieście Zachodnie (69), Czyste (49) i Szosa Krakowska (42). 
Tabela 1. Rozmieszczenie przedsiębiorstw według różnych jednostek i grup jednostek administracyjnych i urbanistycznych (gminy, dzielnice, rejony urbanistyczne, części Warszawy)

\begin{tabular}{|c|c|c|c|c|c|c|c|c|}
\hline \multirow[t]{2}{*}{ Jednostka } & \multicolumn{2}{|c|}{ Ogółem } & \multicolumn{2}{|c|}{$10-100 \mathrm{mln} z \mathrm{l}$} & \multicolumn{2}{|c|}{$100-1000 \mathrm{mln} z \mathrm{z}$} & \multicolumn{2}{|c|}{$\begin{array}{l}\text { powyżej } \\
1 \text { mld zl }\end{array}$} \\
\hline & liczba & $\%$ & liczba & $\%^{*}$ & liczba & $\%^{*}$ & liczba & $\%^{*}$ \\
\hline WARSZAWA & 1343 & 100,0 & 985 & 100,0 & 301 & 100,0 & 57 & 100,0 \\
\hline gm. CENTRUM & 941 & 70,1 & 660 & 67,0 & 232 & 77,1 & 49 & 86,0 \\
\hline WARSZAWA pr. & 246 & 18,3 & 199 & 20,2 & 41 & 13,6 & 6 & 10,5 \\
\hline gm. CENTRUM pr. & 120 & 8,9 & 91 & 9,2 & 26 & 8,6 & 3 & 5,3 \\
\hline dz. Praga Pd. & 71 & 5,3 & 55 & 5,6 & 16 & 5,3 & 0 & 0,0 \\
\hline dz. Praga Pn. & 49 & 3,6 & 36 & 3,7 & 10 & 3,3 & 3 & 5,3 \\
\hline gm. BIALOLEKKA & 57 & 4,2 & 47 & 4,8 & 9 & 3,0 & 1 & 1,8 \\
\hline gm. REMBERTÓW & 11 & 0,8 & 9 & 0,9 & 1 & 0,3 & 1 & 1,8 \\
\hline gm. TARGÓWEK & 27 & 2,0 & 24 & 2,4 & 2 & 0,7 & 1 & 1,8 \\
\hline gm. WAWER & 31 & 2,3 & 28 & 2,8 & 3 & 1,0 & 0 & 0,0 \\
\hline WARSZAWA I. & 1097 & 81,7 & 786 & 79,8 & 260 & 86,4 & 51 & 89,5 \\
\hline gm. Centrum 1 . & 821 & 61,1 & 569 & 57,8 & 206 & 68,4 & 46 & 80,7 \\
\hline dz. Śródmieście & 296 & 22,0 & 210 & 21,3 & 71 & 23,6 & 15 & 26,3 \\
\hline r.u. Centrum-Południe & 113 & 8,4 & 82 & 8,3 & 26 & 8,6 & 5 & 8,8 \\
\hline r.u. Centrum-Północ & 88 & 6,6 & 60 & 6,1 & 24 & 8,0 & 4 & 7,0 \\
\hline r.u. Powiśle-Północ & 30 & 2,2 & 20 & 2,0 & 7 & 2,3 & 3 & 5,3 \\
\hline dz. Mokotów & 209 & 15,6 & 145 & 14,7 & 51 & 16,9 & 13 & 22,8 \\
\hline r.u. Mokotów Stary & 32 & 2,4 & 24 & 2,4 & 6 & 2,0 & 2 & 3,5 \\
\hline r.u. Czerniaków-Wilanów & 40 & 3,0 & 31 & 3,1 & 9 & 3,0 & 0 & 0,0 \\
\hline $\begin{array}{l}\text { r.u. PDPS (w dz. Moko- } \\
\text { tów i gm. Ursynów) }\end{array}$ & 100 & 7,4 & 62 & 6,3 & 31 & 10,3 & 7 & 12,3 \\
\hline dz. Ochota & 79 & 5,9 & 51 & 5,2 & 22 & 7,3 & 6 & 10,5 \\
\hline r.u. Szosa Krakowska & 42 & 3,1 & 23 & 2,3 & 15 & 5,0 & 4 & 7,0 \\
\hline dz. Wola & 191 & 14,2 & 129 & 13,1 & 52 & 17,3 & 10 & 17,5 \\
\hline r.u. Czyste & 49 & 3,6 & 36 & 3,7 & 10 & 3,3 & 3 & 5,3 \\
\hline r.u. Śródmieście Zachodnie & 69 & 5,1 & 37 & 3,8 & 25 & 8,3 & 7 & 12,3 \\
\hline dz. Żoliborz & 46 & 3,4 & 34 & 3,5 & 10 & 3,3 & 2 & 3,5 \\
\hline gm. BEMOWO & 22 & 1,6 & 18 & 1,8 & 4 & 1,3 & 0 & 0,0 \\
\hline gm. BIELANY & 47 & 3,5 & 40 & 4,1 & 6 & 2,0 & 1 & 1,8 \\
\hline gm. URSUS & 20 & 1,5 & 18 & 1,8 & 2 & 0,7 & 0 & 0,0 \\
\hline gm. URSYNÓW & 68 & 5,1 & 58 & 5,9 & 9 & 3,0 & 1 & 1,8 \\
\hline gm. WILANÓW & 14 & 1,0 & 12 & 1,2 & 2 & 0,7 & 0 & 0,0 \\
\hline gm. WLOCHY & 105 & 7,8 & 71 & 7,2 & 31 & 10,3 & 3 & 5,3 \\
\hline
\end{tabular}

* wszystkie udziały obliczono w stosunku do liczby ogólem przedsiębiorstw w Warszawie w poszczególnych grupach

skróty: 1. - część lewobrzeżna: pr. - część prawobrzeżna; gm. - gmina; dz. - dzielnica w obrębie gminy Warszawa-Centrum; r.u. - rejon urbanistyczny; PDPS - Południowa Dzielnica Przemysłowo-Składowa (Słuźewiec Południowy) 

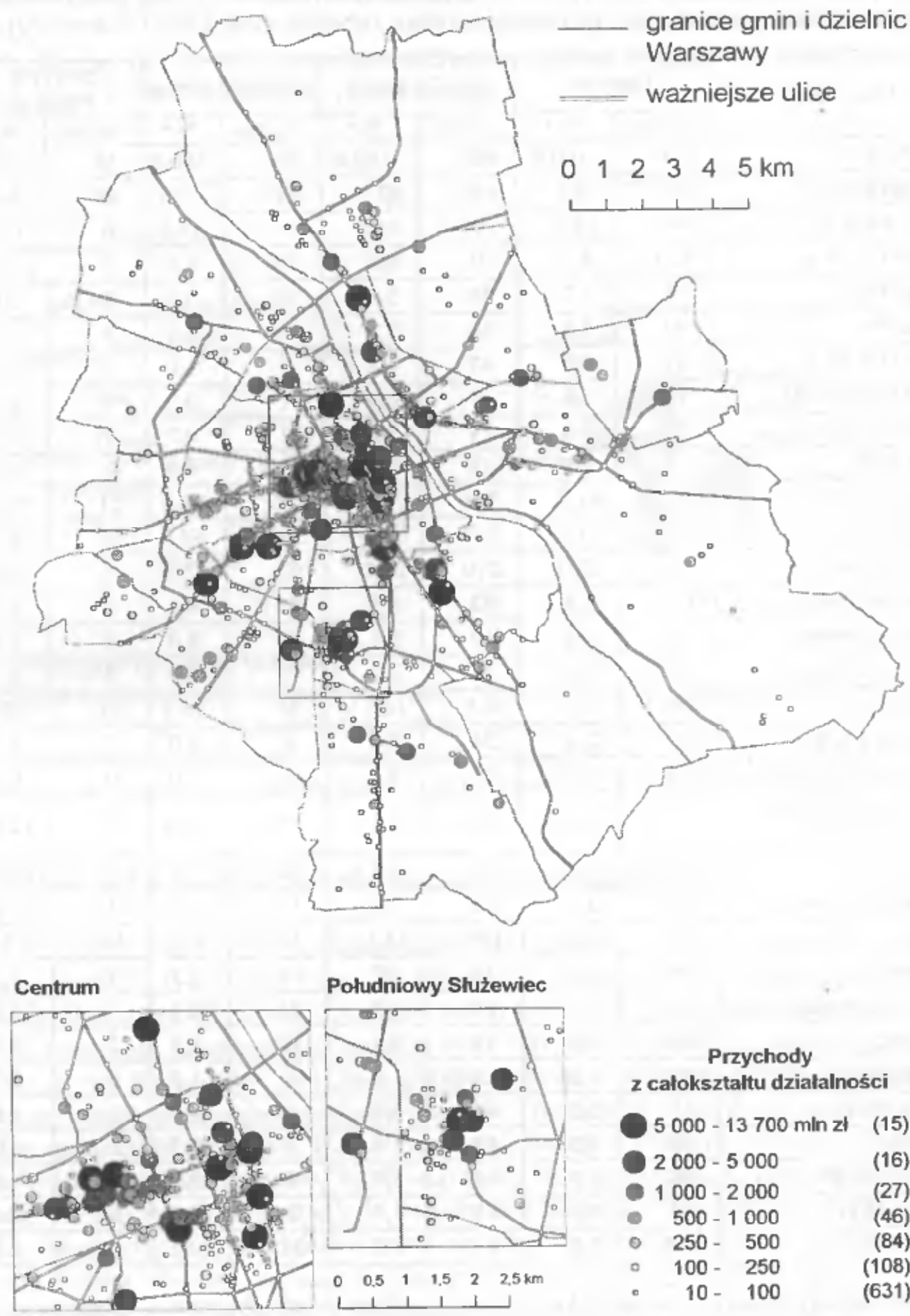

Poludniowy Shužewiec

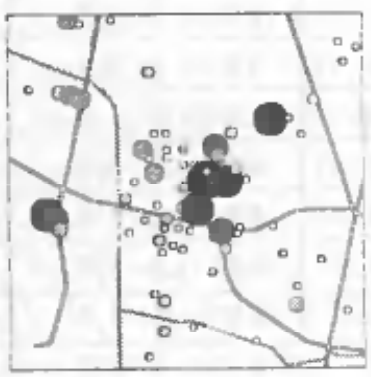

$\begin{array}{llllll}0 & 0.5 & 1 & 1.5 & 2 & 2.5 \mathrm{~km}\end{array}$

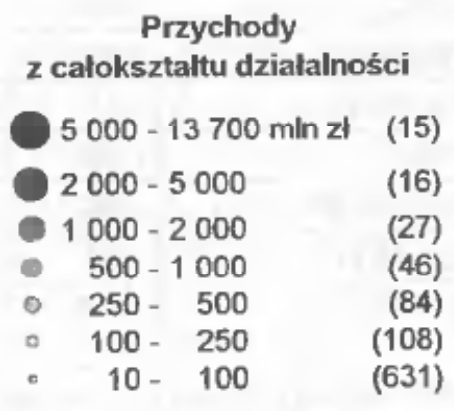

Ryc. 2. Rozmieszczenie głównych siedzib ważniejszych przedsiębiorstw w Warszawie w 1999 r. (przychody przedsiębiorstw o siedzibach pod tym samym adresem zsumowano) 
Najogólniejszą prawidłowością w rozmieszczeniu siedzib przedsiębiorstw jest duża dysproporcja pomiędzy lewo- i prawobrzeżną Warszawą. Lewobrzeżna część Warszawy koncentrowała $81,7 \%$ siedzib, które osiagnęły $88,4 \%$ przychodów badanych przedsiębiorstw. Większą koncentracją cechowało się położenie firm przedsiębiorstw dużych.

Główny obszar koncentracji rozmieszczenia siedzib ważniejszych przedsiębiorstw nie jest administracyjnie spójny, bowiem rozciąga się w środkowo-zachodniej części dzielnicy Śródmieście, południowo-wschodniej części Woli i północno-wschodnich obrzeżach Ochoty. Oprócz tradycyjnego obszaru koncentracji siedzib przedsiębiorstw istnieje kilka mniejszych, z których na uwagę zasługują:

1. obszar Południowego Służewca w dzielnicy Mokotów;

2. obszar wzdłuż Alei Jerozolimskich ciagnący się od dzielnicy Ochota do gminy Warszawa-Włochy;

3. obszar północnego Mokotowa, wzdhuż ulicy Czerniakowskiej (głównie rejon urbanistyczny Sielce) i Alei Witosa, mający swe przedłużenie na zachodzie na Starym Mokotowie.

\section{Struktura wielkościowa}

Spośród siedzib 10 największych przedsiębiorstw 8 było zlokalizowanych $w$ gminie Warszawa-Centrum, w tym 4 w dzielnicy Śródmieście. Z kolei wśród 57 firm o przychodach powyżej $1 \mathrm{mld}$ zł aż 49 firm $(86,0 \%)$ było położonych w gminie Warszawa-Centrum (Tabela 2). Rejony urbanistyczne, w których było dużo siedzib największych przedsiębiorstw to Śródmieście Zachodnie (12,3\%) w dzielnicy Wola, gdzie były siedziby m.in. Pekao, PZU Życie, TUnŻ Commercial Union, Ruch, Elektrim Kable, Impexmetal oraz Goman. Tyle samo w tej grupie siedzib posiadała Południowa Dzielnica PrzemysłowoSkładowa (Służewiec Południowy) w dzielnicy Mokotów (12,3\%) oraz położone w dzielnicy Śródmieście: Centrum Południe $(8,8 \%)$ i Centrum Północ $(7,0 \%)$.

Wyższy stopień koncentracji na obszarach centralnych był charakterystyczny dla firm największych: w grupie przedsiębiorstw o przychodach 10-100 mln zl w gminie Centrum znajdowało się 67,0\% siedzib (w dzielnicach lewobrzeżnych 57,8\%), 100-1000 mln zł$77,1 \%(68,4 \%)$, powyżej I mld $\mathrm{zl}-86,0 \%(80,7 \%)$.

Analiza rozmieszczenia przedsiębiorstw według wielkości przychodów ujawnia, że wartość przychodów największych firm jest najwyższa na obszarze centralnym (Ryc. 3). W dalszej odległości koncentrują się przychody przedsiębiorstw średnich, a na obrzeżach najmniejszych.

Na podstawie powyższych uwag można zatem wstępnie uogólnić, że odległość siedziby od centrum miasta jest odwrotnie proporcjonalna od wielkości ekonomicznej przedsiębiorstwa (im większe przedsiębiorstwo, tym lokuje się bliżej centrum). Tym samym przychody na jednostkę powierzchni są najwyższe na obszarach centralnych (Ryc. 4). 
Tabela 2. Rozmieszczenie przedsiębiorstw według różnych jednostek i grup jednostek administracyjnych i urbanistycznych (gminy, dzielnice, rejony urbanistyczne, części Warszawy)

\begin{tabular}{|c|c|c|c|c|c|c|c|c|}
\hline \multirow[b]{2}{*}{ Jednostka } & \multicolumn{2}{|c|}{ Ogółem } & \multicolumn{2}{|c|}{$10-100 \mathrm{mln} z \mathrm{I}$} & \multicolumn{2}{|c|}{$100-1000 \mathrm{mln} \mathrm{zl}$} & \multicolumn{2}{|c|}{$\begin{array}{l}\text { powyżej } \\
1 \mathrm{mld} \text { zI }\end{array}$} \\
\hline & $\begin{array}{c}\text { suma } \\
\text { przy- } \\
\text { chodów } \\
(\text { mln z) })\end{array}$ & $\%$ & $\begin{array}{l}\text { suma } \\
\text { przy- } \\
\text { chodów } \\
\text { (min zł) }\end{array}$ & $\% *$ & \begin{tabular}{c|}
$\begin{array}{c}\text { suma } \\
\text { przy- } \\
\text { chodów } \\
(\mathrm{mln} z)\end{array}$ \\
\end{tabular} & $\%^{*}$ & \begin{tabular}{|c|} 
suma \\
przy- \\
chodów \\
(mln zl)
\end{tabular} & $\% *$ \\
\hline WARSZAWA & 316269 & 100,0 & 29983 & 100,0 & 90926 & 100,0 & 195360 & 100,0 \\
\hline gm. CENTRUM & 268440 & 84,9 & 20335 & 67,8 & 69724 & 76,7 & 178381 & 91,3 \\
\hline WARSZAWA pr. & 36808 & 11,6 & 6105 & 20,4 & 13971 & 15,4 & 16732 & 8,6 \\
\hline gm, CENTRUM pr. & 23286 & 7,4 & 2690 & 9,0 & 7721 & 8,5 & 12875 & 6,6 \\
\hline dz. Praga Poludnie & 7209 & 2,3 & 1687 & 5,6 & 5522 & 6,1 & 0 & 0,0 \\
\hline dz. Praga Pólnoc & 16077 & 5,1 & 1003 & \begin{tabular}{l|l|}
3,3 \\
\end{tabular} & 2199 & 2,4 & 12875 & 6,6 \\
\hline gm. BIALOLĘKA & 5744 & 1,8 & 1402 & 4,7 & 3134 & 3,4 & 1208 & 0,6 \\
\hline gm. REMBERTÓW & 2216 & 0,7 & 334 & 1,1 & 876 & 1,0 & 1007 & 0,5 \\
\hline gm. TARGÓWEK & 3329 & 1,1 & 848 & 2,8 & 838 & 0,9 & 1643 & 0,8 \\
\hline gm. WAWER & 2233 & 0,7 & 831 & 2,8 & 1402 & 1,5 & 0 & 0,0 \\
\hline WARSZAWA I. & 279461 & 88,4 & 23878 & 79,6 & 76955 & 84,6 & 178627 & 91,4 \\
\hline gm. Centrum 1. & 245153 & 77,5 & 17645 & 58,9 & 62002 & 68,2 & 165506 & 84,7 \\
\hline dz. Śródmieście & 99243 & 31,4 & 6444 & 21,5 & 22130 & 24,3 & 70669 & 36,2 \\
\hline r.u. Centrum-Południe & 36437 & 11,5 & 2399 & 8,0 & 7555 & 8,3 & 26483 & 13,6 \\
\hline r.u. Centrum-Pólnoc & 24021 & 7,6 & 1973 & 6,6 & 8578 & 9,4 & 13470 & 6,9 \\
\hline r.u. Powišle-Pólnoc & 19499 & 6,2 & 475 & 1,6 & 1243 & 1,4 & 17780 & 9,1 \\
\hline dz. Mokotów & 61192 & 19,3 & 4352 & 14,5 & 15448 & 17,0 & 41391 & 21,2 \\
\hline r.u. Mokotów Stary & 14035 & 4,4 & 659 & 2,2 & 1524 & 1,7 & 11852 & 6,1 \\
\hline r.u. Czerniaków-Wilanów & 3238 & 1,0 & 1041 & 3,5 & 2197 & 2,4 & \begin{tabular}{l|l}
0 & \\
\end{tabular} & 0,0 \\
\hline $\begin{array}{l}\text { r.u PDPS (w dz. Moko- } \\
\text { tów i gm. Ursynów) }\end{array}$ & 25744 & 8,1 & 1770 & 5,9 & 10519 & 11,6 & 13455 & 6,9 \\
\hline dz. Ochota & 29587 & 9,4 & 1677 & 5,6 & 6823 & 7,5 & 21087 & 10,8 \\
\hline r.u. Szosa Krakowska & 20152 & 6,4 & 931 & 3,1 & 4578 & 5,0 & 14643 & 7,5 \\
\hline dz. Wola & 48345 & 15,3 & 3826 & 12,8 & 14747 & 16,2 & 29772 & 15,2 \\
\hline r.u. Czyste & 11624 & 3,7 & 1083 & 3,6 & 2742 & 3,0 & $7799^{\circ}$ & 4,0 \\
\hline r.u. Śródmieście Zachodnie & 29571 & 9,3 & 1187 & 4,0 & 6411 & 7,1 & 21973 & 11,2 \\
\hline dz Żoliborz & 6787 & 2,1 & 1346 & 4,5 & 2854 & 3,1 & 2587 & 1,3 \\
\hline gm. BEMOWO & 1259 & 0,4 & 508 & 1,7 & 751 & 0,8 & 0 & 0,0 \\
\hline gm. BIELANY & 3464 & 1,1 & 1077 & 3,6 & 1337 & 1,5 & 1050 & 0,5 \\
\hline gm. URSUS & 1083 & 0,3 & 536 & 1,8 & 547 & 0,6 & 0 & 0,0 \\
\hline gm. URSYNÓW & 6535 & 2,1 & 1717 & 5,7 & 3259 & 3,6 & 1559 & 0,8 \\
\hline gm. WILANÓW & 1261 & 0,4 & 291 & 1,0 & 970 & 1,1 & 0 & 0,0 \\
\hline gm. WLOCHY & 20705 & 6,5 & 2104 & 7,0 & 8088 & 8,9 & 10512 & 5,4 \\
\hline
\end{tabular}

* wszystkie udziały obliczono w stosunku do sumy przychodów analizowanych przedsiębiorstw w Warszawie w poszczególnych grupach

skróty: I. - część lewobrzeźna; pr. - część prawobrzeżna; gm. - gmina; dz. - dzielnica w obrębie gminy Warszawa-Centrum: r.u. - rejon urbanistyczny; PDPS - Południowa Dzielnica Przemysłowo-Składowa (Służewiec Południowy) 


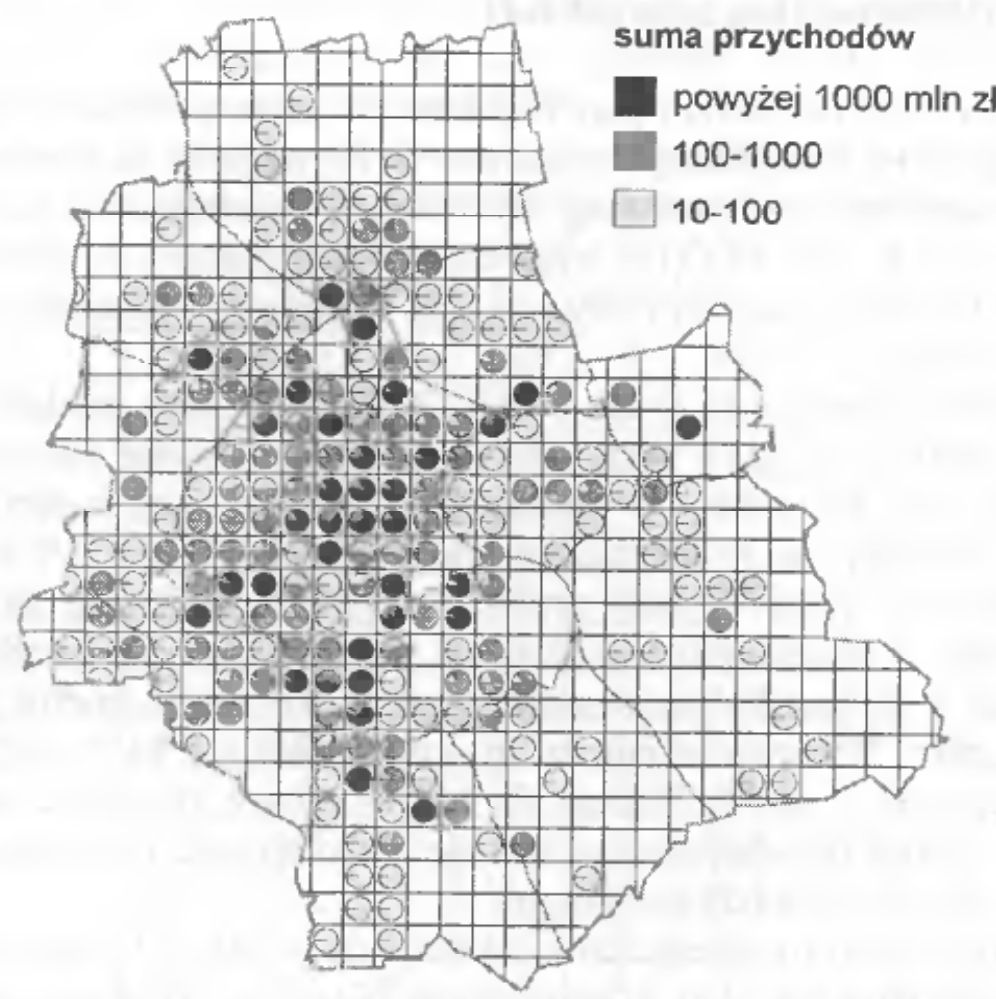

Ryc. 3. Struktura rozmieszczenia przychodów według głównych siedzib przedsiębiorstw w Warszawie w 1999 r. zagregowanych w kwadratach o boku 1 km

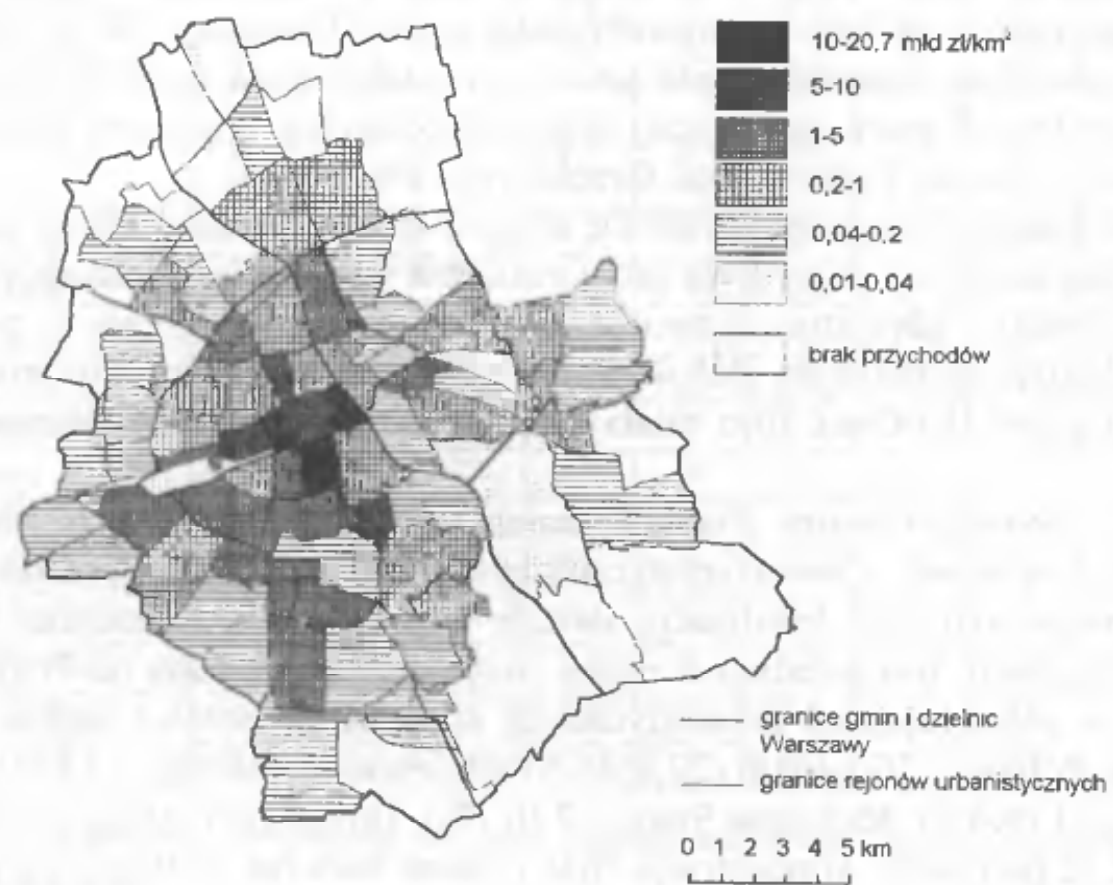

Ryc. 4. Przychody ważniejszych przedsiębiorstw w rejonach urbanistycznych w Warszawie w 1999 r. Uwzględniono przedsiębiorstwa o przychodach co najmniej $10 \mathrm{mln}$ zł 


\section{Struktura rodzajowa wedlug sekcji EKD}

Analiza rozmieszczenia siedzib przedsiębiorstw została przeprowadzona $\mathrm{w}$ grupach sekcji EKD (Europejskiej Klasyfikacji Działalności). Ze względu na stopień podobieństwa działalności i reprezentatywność poszczególnych sekcji wyodrębniono następujące grupy: sekcje DE, F, GH, I, J, K oraz ACO (ze względu na ograniczoność miejsca w tabeli przedstawiono jeszcze bardziej zgeneralizowany podział). Najliczniej reprezentowana była grupa GH (545 przedsiębiorstw).

Przedsiębiorstwa należące do grupy sekcji DEF (działalność produkcyjna, zaopatrywanie w energię elektryczną, gaz i wodę oraz budownictwo) swoje siedziby lokalizowały na obszarze niemal całej Warszawy. W gminie Warszawa-Centrum mieściło się blisko 2/3 liczby wszystkich siedzib, zaś w Warszawie lewobrzeżnej - blisko 1/3 (Tabela 3). Taki rozkład koncentracji był spowodowany przede wszystkim istnieniem stosunkowo dużej liczby przedsiębiorstw o mniejszych przychodach, położonych w strefie zewnętrznej. Okazuje się bowiem, że w przypadku porównania sumy wartości przychodów poszczególnych firm, na terenie gminy Warszawa-Centrum koncentrowało się $84,2 \%$ przychodów, a w Warszawie lewobrzeżnej - 76,9\% (Tabela 4). Innymi słowy, podobnie jak w przypadku zbioru wszystkich siedzib przedsiębiorstw, istnieje prawidłowośc polegająca na lokowaniu się siedzib dużych firm na obszarze centralnym.

Analizując dodatkowo rozmieszczenie siedzib firm w sekcji F (budownictwo) mamy do czynienia ze stosunkowo dużym rozproszeniem (Ryc. 5). Podobnie, jak w przypadku poprzednio omawianych sekcji, dotyczy to przede wszystkim przedsiębiorstw mniejszych.

W grupie sekcji GH (handel hurtowy i detaliczny, naprawy oraz hotele i restauracje) występowała także koncentracja rozmieszczenia głównych siedzib na obszarze centralnym z wyraźną dysproporcją na lewo- i prawobrzeżną część Warszawy. W tej grupie sekcji obserwowane było także rozmieszczenie siedzib przedsiębiorstw poza obszarem centralnym wzdłuż określonych pasm, najczęściej dróg wylotowych z Warszawy (np. Al. Jerozolimskie, Al. Krakowska, ul. Puławska, ul. Grochowska-Płowiecka).

Dużą koncentracją charakteryzowała się sekcja I (transport, gospodarka magazynowa i łączność). Istotną cechą tej grupy była także struktura wielkościowa przedsiębiorstw pod względem przychodów, gdyż stosunkowo dużo podmiotów w tej grupie to. przedsiębiorstwa duże. Większość siedzib była zlokalizowana na obszarze dzielnic Śródmieście, Wola i Ochota. Tylko niewielka część firm miała swe siedziby na obszarze Warszawy prawobrzeżnej.

Najbardziej skoncentrowany charakter miała lokalizacja głównych siedzib sekcji J (pośrednictwo finansowe). Charakterystyczna była także najwyższa spośród wszystkich sekcji dysproporcja pomiędzy lokalizacją siedzib w prawo- i lewobrzeżnej Warszawie: spośród 114 wszystkich firm zaledwie 4 miały swoje główne siedziby na Pradze. Równocześnie łącznie w kilku rejonach urbanistycznych mieściła się połowa siedzib. Były to 4 rejony: Centrum Północ - 26 siedzib (22,8\%), Śródmieście Zachodnie - 14 (12,3\%), Centrum Południe - $11(9,6 \%)$, Mokotów Stary - $7(6,1 \%)$. Biorąc pod uwage przychody kontrolowane przez te podmioty, koncentracja była jeszcze większa, bowiem wymienione 58 firm osiągnęło 57,8\% wszystkich przychodów. Równocześnie w 3 dzielnicach (Śródmieście, Wola, Mokotów) kontrolowane było 97,1\% przychodów. 
Tabela 3. Rozmieszczenie przedsiębiorstw według różnych jednostek i grup jednostek administracyjnych i urbanistycznych (gminy, dzielnice, rejony urbanistyczne, części Warszawy) i przychodów w grupach sekcji EKD

\begin{tabular}{|c|c|c|c|c|c|c|c|c|c|c|}
\hline \multirow{2}{*}{ Jednostka } & \multicolumn{2}{|c|}{ Sekcje DEF } & \multicolumn{2}{|c|}{ Sekcje GH } & \multicolumn{2}{|c|}{ Sekcja I } & \multicolumn{2}{|c|}{ Sekcje JK } & \multicolumn{2}{|c|}{ Inne sekcje } \\
\hline & liczba & $\%^{*}$ & liczba & $\% *$ & liczba & $\% *$ & liczba & $\%^{*}$ & liczba & $\% *$ \\
\hline WARSZAWA & 372 & 100,0 & 545 & 100,0 & 66 & 100,0 & 322 & 100,0 & 38 & 100,0 \\
\hline gm. CENTRUM & 242 & 65,1 & 355 & 65,1 & 48 & 72,7 & 262 & 81,4 & 34 & 89,5 \\
\hline WARSZAWA pr. & 103 & 27,7 & 90 & 16,5 & 13 & 19,7 & 37 & 11,5 & 3 & 7,9 \\
\hline gm. CENTRUM pr. & 44 & 11,8 & 44 & 8,1 & 4 & 6,1 & 25 & 7,8 & 3 & 7,9 \\
\hline dz. Praga Południe & 27 & 7,3 & 28 & 5,1 & 4 & 6,1 & 10 & 3,1 & 2 & 5,3 \\
\hline dz. Praga Północ & 17 & 4,6 & 16 & 2,9 & 0 & 0,0 & 15 & 4,7 & I & 2,6 \\
\hline gm. BIALOLEKA & 34 & 9,1 & 18 & 3,3 & 3 & 4,5 & 2 & 0,6 & 0 & 0,0 \\
\hline gm. REMBERTÓW & 5 & 1,3 & 3 & 0,6 & 3 & 4,5 & 0 & 0,0 & 0 & 0,0 \\
\hline gm. TARGÓWEK & 11 & 3,0 & 11 & 2,0 & 3 & 4,5 & 2 & 0,6 & 0 & 0,0 \\
\hline gm. WAWER & 9 & 2,4 & 14 & 2,6 & 0 & 0,0 & 8 & 2,5 & 0 & 0,0 \\
\hline WARSZAWA 1. & 269 & 72,3 & 455 & 83,5 & 53 & 80,3 & 285 & 88,5 & 35 & 92,1 \\
\hline gm. Centrum I. & 198 & 53,2 & 311 & 57,1 & 44 & 66,7 & 237 & 73,6 & 31 & 81,6 \\
\hline dz. Śródmieście & 62 & 16,7 & 94 & 17,2 & 20 & 30,3 & 110 & 34,2 & 10 & 26,3 \\
\hline r.u. Centrum-Pd. & 24 & 6,5 & 42 & 7,7 & 8 & 12,1 & 33 & 10,2 & 6 & 15,8 \\
\hline r.u. Centrum-Pn. & 13 & 3,5 & 28 & 5,1 & 6 & 9.1 & 40 & 12,4 & 1 & 2,6 \\
\hline r.u. Powiśle-Pn. & 7 & 1,9 & 8 & 1,5 & 4 & 6,1 & 11 & 3,4 & 0 & 0,0 \\
\hline dz. Mokotów & 57 & 15,3 & 80 & 14,7 & 1 & 1,5 & 60 & 18,6 & 11 & 28,9 \\
\hline r.u. Mokotów Stary & 11 & 3,0 & 3 & 0,6 & 0 & 0,0 & 15 & 4,7 & 3 & 7,9 \\
\hline r.u. Czerniaków-Wil. & 4 & 1,1 & 25 & 4,6 & 0 & 0,0 & 8 & 2,5 & 3 & 7,9 \\
\hline $\begin{array}{l}\text { r.u. PDPS (w dz. } \\
\text { Mokotów i gm. } \\
\text { Ursynów) }\end{array}$ & 26 & 7,0 & 45 & 8.3 & 2 & 3,0 & 21 & 6,5 & 6 & 15,8 \\
\hline dz. Ochota & 20 & 5,4 & 39 & 7,2 & 6 & 9,1 & 13 & 4,0 & 1 & 2,6 \\
\hline r.u. Szosa Krakowska & 12 & 3,2 & 20 & 3,7 & 3 & 4,5 & 7 & 2,2 & 0 & 0,0 \\
\hline dz. Wola & 50 & 13,4 & 76 & 13,9 & 15 & 22,7 & 42 & 13,0 & 8 & 21,1 \\
\hline r.u. Czyste & 13 & 3,5 & 20 & 3,7 & 5 & 7,6 & 11 & 3,4 & 0 & 0.0 \\
\hline r.u. Śródmicście Zach & 19 & 5,1 & 23 & 4,2 & 3 & 4,5 & 23 & 7,1 & 1 & 2,6 \\
\hline dz. Żolibor 2 & 9 & 2,4 & 22 & 4,0 & 2 & 3,0 & 12 & 3,7 & 1 & 2,6 \\
\hline gm. BEMOWO & 2 & 0,5 & 11 & 2,0 & 0 & 0,0 & 9 & 2,8 & 0 & 0,0 \\
\hline gm. BIELANY & 17 & 4,6 & 21 & 3,9 & 0 & 0,0 & 9 & 2,8 & 0 & 0,0 \\
\hline gm. URSUS & 6 & 1,6 & 11 & 2,0 & 0 & 0,0 & 3 & 0,9 & 0 & 0,0 \\
\hline gm. URSYNÓW & 16 & 4,3 & 35 & 6,4 & 1 & 1,5 & 13 & 4,0 & 3 & 7,9 \\
\hline gm. WILANÓW & 1 & 0,3 & 10 & 1,8 & 0 & 0,0 & 2 & 0,6 & 1 & 2,6 \\
\hline gm. WLOCHY & 29 & 7,8 & 56 & 10,3 & 8 & 12,1 & 12 & 3,7 & 0 & 0,0 \\
\hline
\end{tabular}

* wszystkie udziały obliczono w stosunku do liczby ogółem analizowanych przedsiębiorstw w Warszawie w poszczególnych gnupach

skróty: I. - część lewobrzeżna; pr. - część prawobrzeżna; gm. - gmina; dz. - dzielnica w obrębie gminy Warszawa-Centrum; r.u. - rejon urbanistyczny; PDPS - Południowa Dzielnica Przemysłowo-Składowa (Służewiec Południowy) 
Tabela 4. Rozmieszczenie przedsiębiorstw według jednostek różnych jednostek i grup jednostek administracyjnych i urbanistycznych (gminy, dzielnice, rejony urbanistyczne, części Warszawy) i przychodów w grupach sekcji EKD

\begin{tabular}{|c|c|c|c|c|c|c|c|c|c|c|}
\hline \multirow[b]{2}{*}{ Jednostka } & \multicolumn{2}{|c|}{ Sekcje DEF } & \multicolumn{2}{|c|}{ Sekcje GH } & \multicolumn{2}{|c|}{ Sekcja I } & \multicolumn{2}{|c|}{ Sekcje JK. } & \multicolumn{2}{|c|}{ Inne sekcje } \\
\hline & $\begin{array}{l}\text { przy- } \\
\text { chody } \\
\text { (mln zl }\end{array}$ & $\% *$ & $\begin{array}{c}\text { przy- } \\
\text { chody } \\
\text { (mln zl }\end{array}$ & $\%^{*}$ & $\begin{array}{l}\text { przy- } \\
\text { chody } \\
\text { (mln zl }\end{array}$ & $\%^{*}$ & $\begin{array}{l}\text { przy- } \\
\text { chody } \\
\text { (mln zt }\end{array}$ & $\% *$ & \begin{tabular}{|l|} 
przy- \\
chody \\
(mln zt
\end{tabular} & $\%^{*}$ \\
\hline WARSZAWA & 82278 & 100,0 & 94581 & 100,0 & 41681 & 100,0 & 89044 & 100,0 & 8635 & 100,0 \\
\hline gm. CENTRUM & 69282 & 84,2 & 68695 & 72,6 & 36333 & 87,2 & 85540 & 96,1 & 8539 & 98,9 \\
\hline WARSZAWA pr. & 18967 & 23,1 & 12611 & 13,3 & 796 & 1,9 & 1764 & 2,0 & 2670 & 30,9 \\
\hline gm. CENTRUM pr. & 10456 & 12,7 & 8558 & 9,0 & 169 & 0,4 & 1434 & 1,6 & 2670 & 30,9 \\
\hline dz. Praga Pd. & 2233 & 2,7 & 3540 & 3,7 & 169 & 0,4 & 671 & 0,8 & 596 & 6.9 \\
\hline dz. Praga Pn. & 8223 & 10,0 & 5018 & 5,3 & 0 & $\overline{0,0}$ & 763 & 0,9 & 2074 & 24,0 \\
\hline gm. BIALOLĘKA & 3509 & 4,3 & 1699 & 1,8 & 498 & 1,2 & 38 & 0,0 & 0 & 0,0 \\
\hline gm. REMBERTÓW & 1167 & 1,4 & 971 & 1,0 & 79 & 0,2 & 0 & 0,0 & 0 & $\overline{0,0}$ \\
\hline gm. TARGÓWEK & 2289 & 2.8 & 956 & 1,0 & 50 & 0,1 & 33 & 0,0 & 0 & 0,0 \\
\hline gm. WAWER & 1547 & 1,9 & 427 & 0,5 & 0 & 0,0 & 259 & 0,3 & 0 & 0.0 \\
\hline WARSZAWA I. & 63311 & 76,9 & 81970 & 86,7 & 40884 & 98,1 & 87280 & 98,0 & 5965 & 69,1 \\
\hline gm. Centrum 1. & 58826 & 71,5 & 60137 & 63,6 & 36164 & 86,8 & 84106 & 94,5 & 5870 & 68,0 \\
\hline dz. Śródmieścic & 29853 & 36,3 & 25209 & 26,7 & 18124 & 43,5 & 25398 & 28,5 & 658 & 7,6 \\
\hline r.u. Centrum-Pd. & 24371 & 29,6 & 3542 & 3,7 & 320 & 0,8 & 8049 & 9,0 & 155 & 1,8 \\
\hline r.u. Centrum-Pn. & 1309 & 1,6 & 8988 & 9,5 & 4416 & 10,6 & 8931 & 10,0 & 378 & 4,4 \\
\hline r.u. Powiśle-Pn. & 1346 & 1,6 & 477 & 0,5 & 13317 & 32,0 & 4357 & 4,9 & 0 & 0,0 \\
\hline dz. Mokotów & 15633 & 19,0 & 12716 & 13,4 & 287 & 0,7 & 28149 & 31,6 & 4407 & 51,0 \\
\hline r.u. Mokotów Stary & 2204 & 2,7 & 89 & 0,1 & 0 & 0,0 & 11400 & 12,8 & 342 & 4,0 \\
\hline r.u. Czerniaków-Wil. & 458 & 0,6 & 1828 & 1,9 & 0 & 0,0 & 631 & 0,7 & 322 & 3,7 \\
\hline $\begin{array}{l}\text { r.u. PDPS (w dz. } \\
\text { Mokotów i gm. } \\
\text { Ursynów) }\end{array}$ & 9066 & 11,0 & 11145 & 11,8 & 299 & 0,7 & 1686 & 1,9 & 3546 & 41,1 \\
\hline dz. Ochota & 5334 & 6.5 & 4755 & 5,0 & 15371 & 36,9 & 4113 & 4,6 & 14 & 0,2 \\
\hline r.u. Szosa Krakowska & 4330 & 5,3 & 3669 & 3,9 & 11851 & 28,4 & 302 & 0,3 & 0 & 0,0 \\
\hline dz. Wola & 6604 & 8,0 & 13480 & 14,3 & 2193 & 5,3 & 25252 & 28,4 & 764 & 8,8 \\
\hline r.u. Cryste & 1093 & 1,3 & 2022 & 2,1 & 552 & 1,3 & 7956 & 8,9 & 0 & 0,0 \\
\hline r.u. Śródmieście Zach. & 3300 & 4,0 & 8820 & 9,3 & 1101 & 2,6 & 16292 & 18,3 & 58 & 0,7 \\
\hline dz. Zoliborz & 1402 & 1,7 & 3977 & 4,2 & 188 & 0,5 & 1194 & 1,3 & 27 & 0,3 \\
\hline gm. BEMOWO & 34 & 0,0 & 497 & 0,5 & 0 & 0.0 & 728 & 0,8 & 0 & 0,0 \\
\hline gm. BIELANY & 1016 & 1,2 & 2083 & 2,2 & 0 & 0,0 & 364 & 0,4 & 0 & 0,0 \\
\hline gm. URSUS & 567 & 0,7 & 467 & 0,5 & 0 & 0,0 & 49 & 0,1 & 0 & 0,0 \\
\hline gm. URSYNÓW & 701 & 0,9 & 5007 & 5,3 & 12 & 0,0 & 734 & 0,8 & 82 & 0,9 \\
\hline gm. WILANÓW & 377 & 0,5 & 840 & 0,9 & 0 & 0,0 & 31 & 0,0 & 14 & 0,2 \\
\hline gm. WLOCHY & 1790 & 2,2 & 12938 & 13,7 & 4709 & 11,3 & 1268 & 1,4 & 0 & 0,0 \\
\hline
\end{tabular}

* wszystkie udziały obliczono w stosunku do sumy przychodów analizowanych przedsiębiorstw w Warszawie w poszczególnych grupach

skróty: 1. - część lewobrzeżna; pr. - część prawobrzeżna; gm. - gmina; dz. - dzielnica w obrębie gminy Warszawa-Centrum; r.u. - rejon urbanistyczny; PDPS - Południowa Dzielnica Przemysłowo-Składowa (Służewiec Południowy) 

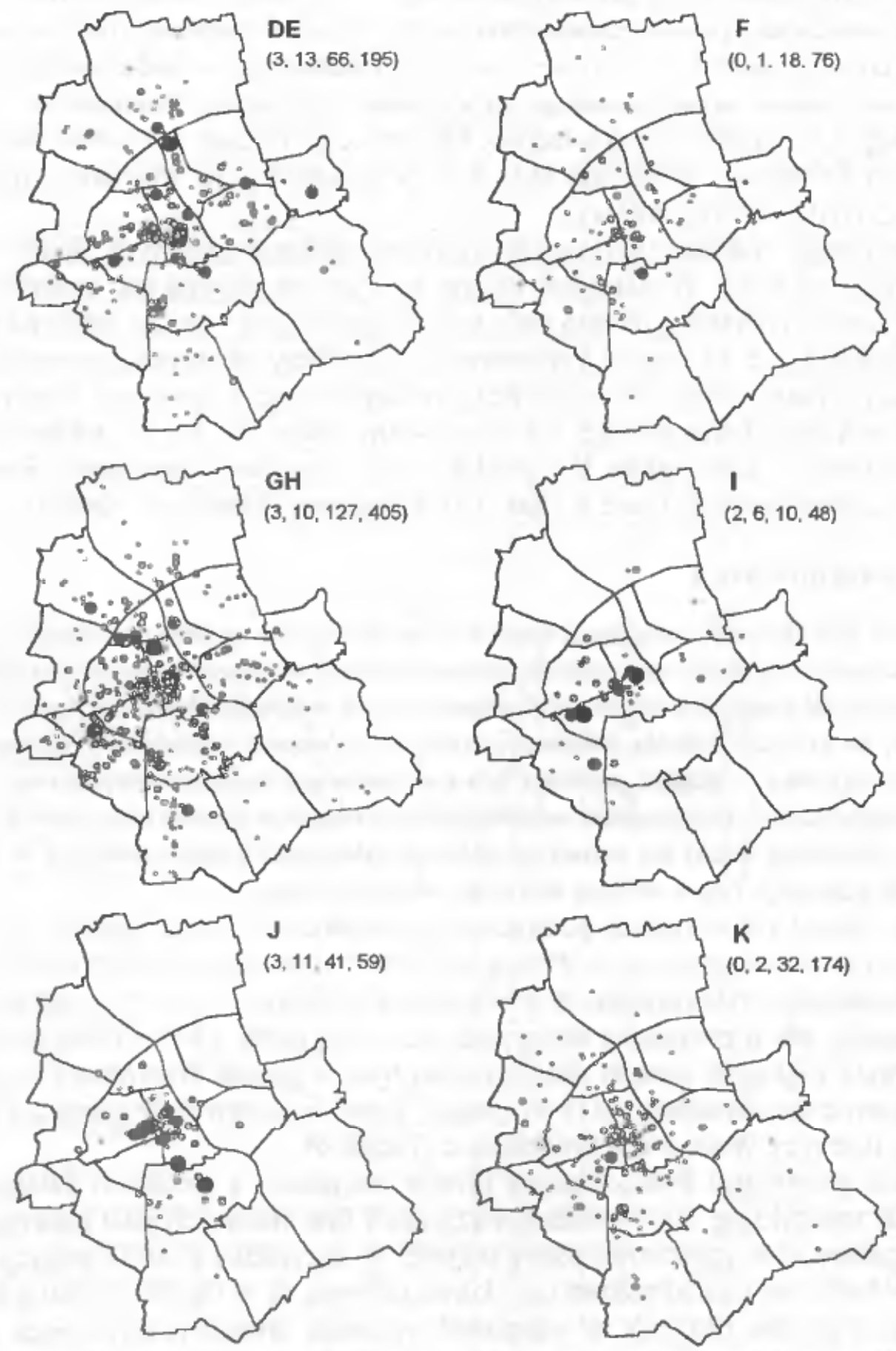

Przychody w mln zl

- $5000-13700$

- $1000-5000$

- $100-1000$

$\cdot 10-100$

Ryc. 5. Rozmieszczenie głównych siedzib przedsiębiorstw w Warszawie w 1999 r. w podziale na sekcje EKD i grupy sekcji

Liczby pod symbolami sekcji oznaczają liczbę przedsiębiorstw o przychodach w wysokości (w kolejności od lewej do prawej): 5000-13700 mln zł, 1000-5000 mln zł, 100-1000 mln zl, 10-100 mln zł 
Cechą charakterystyczną podmiotów sekcji K (obsługa nieruchomości, wynajem i działalność związana z prowadzeniem interesów) było duże rozproszenie, $\mathrm{z}$ dość wyraźną jednak koncentracją siedzib w obrębie dzielnicy Śródmieście, a także niektórych części Mokotowa oraz rejonu urbanistycznego Śródmieście Zachodnie. Rozmieszczenie siedzib w grupie sekcji ACO (rolnictwo, łowiectwo, leśnictwo, górnictwo, górnictwo i kopalnictwo oraz pozostała działalność usługowa) było dość przypadkowe, co wynikało z małej reprezentatywności (tylko 38 podmiotów).

Podsumowując charakterystyczne cechy rozmieszczenia głównych siedzib przedsiębiorstw według struktury działalności, można przyjąć, że największą koncentracją rozmieszczenia siedzib charakteryzowała się sekcja J, najmniejszą - sekcje DE oraz K. Można zatem wstępnie przyjąć, że stopień koncentracji jest zależny od stopnia rozwoju działalności. Lokalizacja siedzib podmiotów dla rodzajów działalności o wyższym stopniu rozwoju (np. usługi finansowe) mają bardziej skoncentrowany charakter, zaś dla podmiotów o niższym stopniu rozwoju (tzw. sektor II - produkcyjny) - bardziej rozproszony. Prawidłowości te zostały zaobserwowane także w skali ogólnokrajowej (Śleszyński 2002a).

\section{Struktura wlasnościowa}

W części poświęconej lokalizacji siedzib przedsiębiorstw według ich struktury własnościowej postawiono pytanie, czy istnieją prawidłowości w przestrzennym rozmieszczeniu funkcji kontrolnych według różnych form własności. Ze względu na szczegółowość posiadanych danych, w których istniała informacja m.in. o głównym udziałowcu według rodzaju własności (państwowa - skarbu państwa lub państwowych osób prawnych oraz własność prywatna i zagraniczna), bez podania udziału procentowego w podmiocie, analiza była dość ograniczona. Niemniej udało się uchwycić główne zależności i prawidłowości w rozmieszczeniu siedzib przedsiębiorstw według struktury własnościowej.

Ogólnie, wśród 153 badanych podmiotów gospodarczych (które znalazły się na Liście 500 największych przedsiębiorstw w Polsce w 1999 r. dziennika „Rzeczpospolita”), w 37 głównym właścicielem było państwo, w 45 - posiadacze prywatni, a w 71 - zagraniczni (Tabela 5). Podobnie, jak w przypadku omawianej wcześniej próby 1343 przedsiębiorstw, również w tej grupie większość siedzib zlokalizowana była w gminie Warszawa-Centrum (124) oraz w Warszawie lewobrzeżnej (131). Przychody przedsiębiorstw były natomiast nieznacznie wyższe w dzielnicy Wola, niż w Śródmieściu (Tabela 6).

Własność państwowa była związana przede wszystkim z obszarem dzielnicy Śródmieście, gdzie mieściło się $30,1 \%$ siedzib wszystkich firm mających jako głównego posiadacza skarb państwa lub państwowe osoby prawne. W przypadku kontrolowanych przychodów było to $45,6 \%$, zaś niemal połowa tego koncentrowała się w obrębie rejonu urbanistycznego Centrum Południe (20,8\%). W niektórych rejonach urbanistycznych poza obszarem centralnym głównym lub jedynym rozporządzającym dochodami było państwo, ale wynikało to $\mathrm{z}$ faktu nieistnienia innych siedzib przedsiębiorstw $\mathrm{w}$ badanej grupie (Ryc. 6A).

Własność prywatna wiązała się również przede wszystkim z dzielnicą Śródmieście, choć w mniejszym stopniu ( $31,1 \%$ liczby firm, 30,5\% przychodów), z czego 1/3 liczby była związana $\mathrm{z}$ rejonem urbanistycznymi Centrum Południe $(11,1 \%)$, a połowa przychodów $\mathrm{z}$ rejonem urbanistycznym Centrum Północ (15,8\%). Z Mokotowem było związane 21,0\% przychodów, zaś z Ochotą - 20,5\%. W strukturze przychodów większy udział zarządzania prywatnego związany był z zachodnią i północną częśsią funkcjonalnego centrum Warszawy (Ryc. 6B). 
Tabela 5. Rozmieszczenie przedsiębiorstw według różnych jednostek $\mathbf{i}$ grup jednostek administracyjnych i urbanistycznych (gminy, dzielnice, rejony urbanistyczne, części Warszawy) i rodzaju kontroli przychodów

\begin{tabular}{|c|c|c|c|c|c|c|c|c|}
\hline \multirow{2}{*}{ Jednostka } & \multicolumn{2}{|c|}{ Ogółem } & \multicolumn{2}{|c|}{ Państwowa } & \multicolumn{2}{|c|}{ Prywatna } & \multicolumn{2}{|c|}{ Zagraniczna } \\
\hline & liczba & $\% *$ & liczba & $\%^{*}$ & liczba & $\% *$ & liczba & $\% *$ \\
\hline WARSZAWA & 153 & $\begin{array}{c}100 \\
0\end{array}$ & 37 & 100,0 & 45 & 100,0 & 71 & 100,0 \\
\hline $\mathrm{gm}$. CENTRUM & 124 & 81,0 & 29 & 78,4 & 40 & 88,9 & 55 & 77,5 \\
\hline WARSZAWA pr. & 22 & 14,4 & 5 & 13,5 & 3 & 6,7 & 14 & 19,7 \\
\hline gm. CENTRUM pr. & 11 & 7,2 & 1 & 2,7 & 2 & 4,4 & 8 & 11,3 \\
\hline dz. Praga Pd & 6 & 3,9 & 0 & 0,0 & 1 & 2,2 & 5 & 7,0 \\
\hline dz. Praga Pn & 5 & 3,3 & 1 & 2,7 & 1 & 2,2 & 3 & 4,2 \\
\hline gm. BIALOLEEKA & 5 & 3,3 & 2 & 5,4 & 1 & 2,2 & 2 & 2,8 \\
\hline gm. REMBERTÓW & 2 & 1,3 & 1 & 2,7 & 0 & 0,0 & 1 & 1,4 \\
\hline gm. TARGÓWEK & 2 & 1,3 & 1 & 2,7 & 0 & 0,0 & 1 & 1,4 \\
\hline gm. WAWER - & 2 & 1,3 & 0 & 0,0 & 0 & 0,0 & 2 & 2,8 \\
\hline WARSZAWA I. & 131 & 85,6 & 32 & 86,5 & 42 & 93,3 & 57 & 80,3 \\
\hline gm. Centrum I. & 113 & 73,9 & 28 & 75,7 & 38 & 84,4 & 47 & 66,2 \\
\hline dz. Śródmieście & 46 & 30,1 & 13 & 35,1 & 14 & 31,1 & 19 & 26,8 \\
\hline r.u. Centrum-Poludnie & 17 & 11,1 & 5 & 13,5 & 5 & 11,1 & 7 & 9,9 \\
\hline r.u. Centrum-Północ & 15 & 9,8 & 4 & 10,8 & 4 & 8,9 & 7 & 9,9 \\
\hline r.u. Powiśle-Północ & 5 & 3,3 & 3 & 8,1 & 1 & 2,2 & 1 & 1,4 \\
\hline dz. Mokotów & 22 & 14,4 & 4 & 10,8 & 8 & 17,8 & 10 & 14,1 \\
\hline r.u. Mokotów Stary & 2 & 1,3 & 1 & 2,7 & 1 & 2,2 & 0 & 0,0 \\
\hline r.u. Czerniaków-Wilanów & 5 & 3,3 & 0 & 0,0 & 2 & 4,4 & 3 & 4,2 \\
\hline $\begin{array}{l}\text { r.u. PDPS (w dz. Moko- } \\
\text { tów i gm. Ursynów) }\end{array}$ & 9 & 5,9 & 1 & 2,7 & 2 & 4,4 & 6 & 8,5 \\
\hline dz. Ochota & 10 & 6,5 & 1 & 2,7 & 3 & 6,7 & 6 & 8,5 \\
\hline r.u. Szosa Krakowska & 6 & 3,9 & 1 & 2,7 & 2 & 4,4 & 3 & 4,2 \\
\hline dz. Wola & 29 & 19,0 & 9 & 24,3 & 9 & 20,0 & 11 & 15,5 \\
\hline r.u. Czyste & 6 & 3,9 & 2 & 5,4 & 1 & 2,2 & 3 & 4,2 \\
\hline $\begin{array}{l}\text { r.u. Środmieście Zachod- } \\
\text { nie }\end{array}$ & 15 & 9,8 & 5 & 13,5 & 5 & 11,1 & 5 & 7,0 \\
\hline dz. Żoliborz & 6 & 3,9 & 1 & 2,7 & 4 & 8,9 & 1 & 1,4 \\
\hline gm. BEMOWO & 1 & 0,7 & 0 & 0,0 & 1 & 2,2 & 0 & 0,0 \\
\hline gm. BIELANY & 3 & 2,0 & 0 & 0,0 & 0 & 0,0 & 3 & 4,2 \\
\hline gm. URSUS & 1 & 0,7 & 1 & 2,7 & 0 & 0,0 & 0 & 0,0 \\
\hline gm. URSYNÓW & 3 & 2,0 & 0 & 0,0 & 0 & 0,0 & 3 & 4,2 \\
\hline gm. WILANÓW & 1 & 0,7 & 0 & 0,0 & 0 & 0,0 & 1 & 1,4 \\
\hline $\mathrm{gm}$. WLOCHY & 9 & 5,9 & 3 & 8,1 & 3 & 6,7 & 3 & 4,2 \\
\hline
\end{tabular}

* wszystkie udzialy obliczono w stosunku do liczby ogółem przedsiębiorstw w Warszawie w poszczególnych grupach

skróty: I. - część lewobrzeżna; pr. - część prawobrzeżna; gm. - gmina; dz. - dzielnica w obrębie gminy Warszawa-Centrum; r.u. - rejon urbanistyczny; PDPS - Południowa Dzielnica Przemysłowo-Składowa (Służewiec Południowy) 
Tabela 6. Rozmieszczenie przedsiębiorstw według róznych jednostek i grup jednostek administracyjnych i urbanistycznych (gminy, dzielnice, rejony urbanistyczne, części Warszawy) i rodzaju kontroli przychodów

\begin{tabular}{|c|c|c|c|c|c|c|c|c|}
\hline \multirow[b]{2}{*}{ Jednostka } & \multicolumn{2}{|c|}{ Ogółem } & \multicolumn{2}{|c|}{ Paŕstwowa } & \multicolumn{2}{|c|}{ Prywatna } & \multicolumn{2}{|c|}{ Zagraniczna } \\
\hline & $\begin{array}{c}\text { suma } \\
\text { przy- } \\
\text { chodów } \\
\text { w mln zt }\end{array}$ & $\% *$ & $\begin{array}{l}\text { suma } \\
\text { przy- } \\
\text { chodów } \\
\text { w mln zł }\end{array}$ & $\% *$ & $\begin{array}{c}\text { suma } \\
\text { przy- } \\
\text { chodów } \\
\text { w mln zl }\end{array}$ & $\%^{*}$ & $\begin{array}{l}\text { suma } \\
\text { przy- } \\
\text { chodów } \\
\text { w mln zt }\end{array}$ & \%* \\
\hline WARSZAWA & 201427 & 100,0 & 100927 & 100,0 & 31170 & 100,0 & 69330 & 100,0 \\
\hline gm. CENTRUM & 176146 & 90,0 & 93085 & 92,2 & 29442 & 94,5 & 53619 & 77,3 \\
\hline WARSZAWA pr. & 24761 & 38,0 & 4898 & 4,9 & 1517 & 4,9 & 18346 & 26,5 \\
\hline gm. CENTRUM pr. & 17140 & 16,4 & 2074 & 2,1 & 1003 & 3,2 & 14063 & 20,3 \\
\hline dz. Praga Poludnie & 3497 & 10,2 & 0 & 0,0 & 666 & 2,1 & 2831 & 4,1 \\
\hline dz. Praga Północ & 13643 & 8,5 & 2074 & 2,1 & 337 & 1,1 & 11232 & 16,2 \\
\hline $\mathrm{gm}$. BIALOLĘKA & 2626 & 19.9 & 1546 & 1,5 & 514 & 1,6 & 566 & 0,8 \\
\hline gm. REME & 1883 & 5,2 & 1007 & 1,0 & 0 & $\overline{0,0}$ & 876 & 1,3 \\
\hline gm. TARGÓWEK & 1914 & 0,8 & 271 & 0,3 & 0 & 0,0 & 1643 & 2,4 \\
\hline gm. W. & 1198 & 5,2 & 0 & 0,0 & 0 & 0,0 & 1198 & 1,7 \\
\hline WAR & 176666 & 10,0 & 96029 & 95,1 & 29653 & 95,1 & 50984 & 73,5 \\
\hline $\mathrm{gm} . \mathrm{C}$ & 159006 & 7,8 & 91011 & 90,2 & 28439 & 91,2 & 39556 & 57,1 \\
\hline dz. Śr & 67112 & 19,9 & 45996 & 45,6 & 9503 & 30,5 & 11613 & 16,8 \\
\hline r.u. Cer & 29035 & 5,0 & 20979 & 20,8 & 2401 & 7,7 & 5655 & 8,2 \\
\hline r.u. Centru & 18008 & 13,4 & 10129 & 10,0 & 4912 & 15,8 & 2967 & 4,3 \\
\hline r.u. Powiśle-Północ & 14956 & 2,2 & 14581 & 14,4 & 195 & 0,6 & 180 & 0,3 \\
\hline dz. Mokot & 35074 & 0,1 & 21268 & 21,1 & 6534 & 21,0 & 7272 & 10,5 \\
\hline r.u. Mok & 9215 & 1,1 & 9001 & 8,9 & 214 & 0,7 & 0 & 0,0 \\
\hline $\begin{array}{r}\text { r.u. } C z \\
\text { Wi }\end{array}$ & 1397 & 0.2 & 0 & 0.0 & 515 & 1.7 & 882 & 1,3 \\
\hline $\begin{array}{l}\text { r.u. PDPS (u } \\
\text { Mokotóv } \\
\text { Ursynów }\end{array}$ & 9199 & 1,3 & 2023 & 2,0 & 1275 & 4,1 & 5901 & 8.5 \\
\hline dz. Ochota & 17678 & 0,2 & 9171 & 9,1 & 6376 & 20,5 & 2131 & 3,1 \\
\hline r.u. Szosa Krak & 13718 & 7,1 & 9171 & 9,1 & 3494 & 11,2 & 1053 & 1,5 \\
\hline dz. Wo & 35213 & 0,0 & 13246 & 13,1 & 4684 & 15,0 & 17283 & 24,9 \\
\hline r.u. & 8861 & 0,0 & 2893 & 2,5 & 408 & 1,3 & 5560 & 8,0 \\
\hline $\begin{array}{l}\text { r.u. Śródmi } \\
\text { chodnie }\end{array}$ & 23626 & 0,0 & 9637 & 9,5 & 3620 & 11,6 & 10369 & 15,0 \\
\hline dz. Żo & 3929 & 0.0 & 1330 & 1,3 & 1342 & 4,3 & 1257 & 1,8 \\
\hline $\mathrm{gm} . \mathrm{B}$ & 197 & 0,0 & 0 & 0,0 & 197 & 0,6 & 0 & 0,0 \\
\hline $\mathrm{gm}$. BI & 1896 & 0,0 & 0 & 0,0 & 0 & 0,0 & 1896 & 2,7 \\
\hline $\mathrm{gm} . \mathrm{U}$ & 405 & 0,0 & 405 & $\overline{0,4}$ & 0 & 0,0 & 0 & 0,0 \\
\hline gm. URSYNÓW & 2281 & 0,0 & 0 & 0,0 & 0 & 0,0 & 2281 & 3,3 \\
\hline gm. WILANÓW & 377 & 0,0 & 0 & 0,0 & 0 & 0,0 & 377 & 0,5 \\
\hline gm. WLOCHY & 12504 & 0,0 & 4613 & 4,6 & 1017 & 3,3 & 6874 & 9,9 \\
\hline
\end{tabular}

* wszystkie udziały obliczono w stosunku do liczby ogólem analizowanych przedsiębiorstw w Warszawie w poszczególnych grupach

skróty: 1. - część lewobrzeżna; pr. - część prawobrzeżna; gm. - gmina; dz. - dzielnica w obrębie gminy Warszawa-Centrum; r.u. - rejon urbanistyczny; PDPS - Południowa Dzielnica Przemysłowo-Składowa (Służewiec Południowy) 
Własność zagraniczna koncentrowała się przede wszystkim w dzielnicy Śródmieście, gdzie mieściło się $26,8 \%$ siedzib firm $\mathrm{z}$ głównym lub jedynym posiadaczem zagranicznym oraz tylko $16,8 \%$ przychodów. Większą koncentrację przychodów zaobserwowano w dzielnicy Wola $(24,9 \%$, głównie w obrębie rejonu urbanistycznego Śródmieście Zachodnie $15,0 \%$ ). Oznacza to, że poza Śródmieściem zlokalizowane są w tej grupie własnościowej siedziby firm większych. W strukturze przychodów według sektorów własności charakterystyczna jest większa rola przedsiębiorstw pod kontrolą kapitału zagranicznego, których siedziby zlokalizowano poza dzielnicą Śródmieście, m.in. na Mokotowie, Południowym Służewcu, Woli, Ursynowie oraz Pradze (Ryc. 6C).
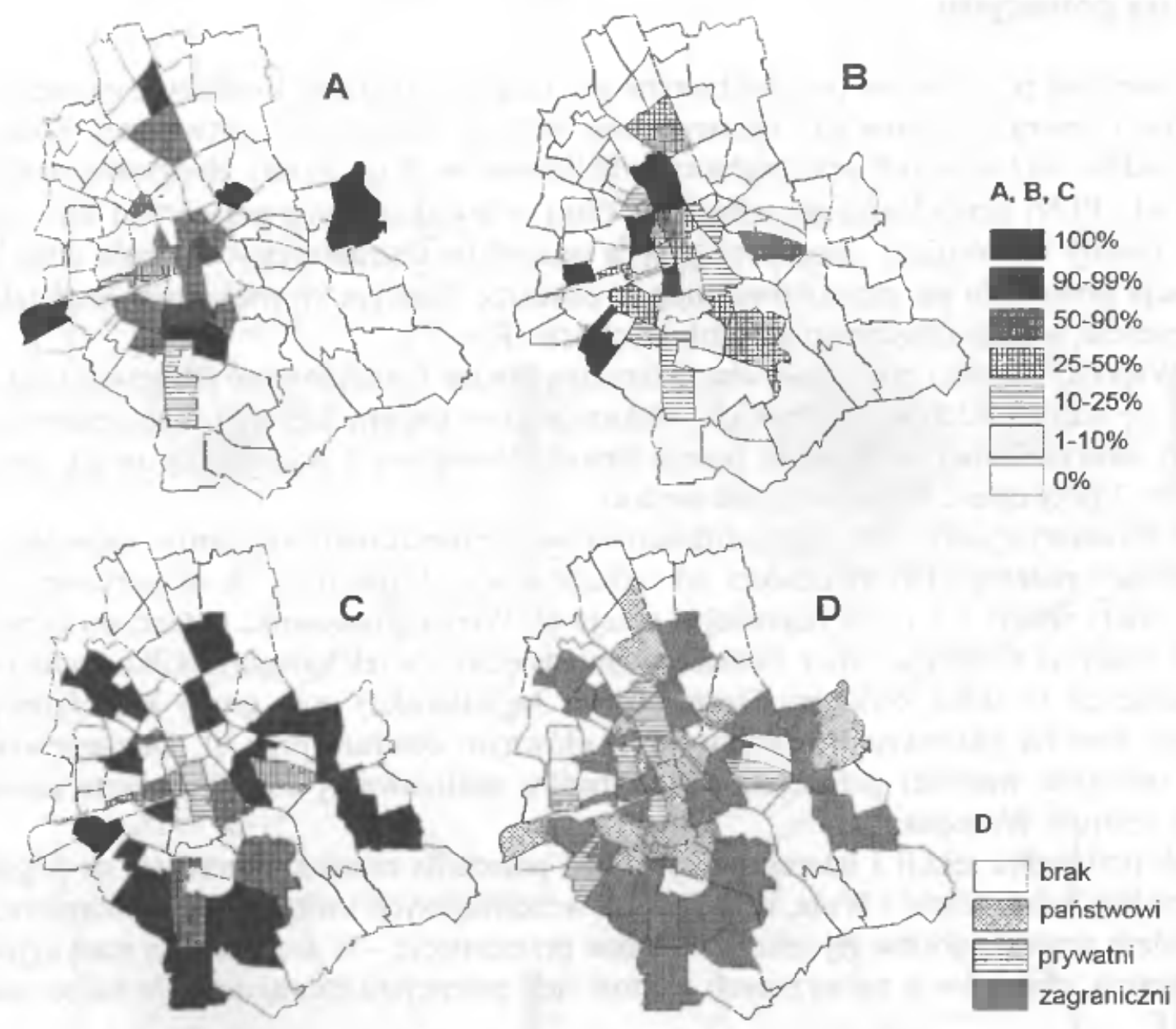

Ryc. 6. Udział przychodów przedsiębiorstw znajdujących się pod kontrolą grup właścicieli według rodzajów własności w rejonach urbanistycznych w Warszawie w 1999 r. Udziały zakwalifikowano na podstawie głównego lub jedynego właściciela (nie zawsze było to $50 \%$ własności)

Kontrola właścicieli: A - państwowa, B - prywatna, C - zagraniczna D - właściciel, pod którego kontrolą znajdowało się najwięcej przychodów 
Można zatem uogólnić, że państwowa przestrzeń zarządzania związana jest przede wszyst$\operatorname{kim}$ z tradycyjnym obszarem centrum. Ponieważ przed 1989 r. miało ono znacznie mniejsze rozmiary niż obecnie (Śleszyński 2002b), można zjawisko to wyjaśnić w ten sposób, że kapitał zagraniczny, a w dużej mierze także prywatny, za siedziby swych firm wybierał nowe lokalizacje, często w atrakcyjnych nowowybudowanych obiektach. Charakterystycznym przykładem jest tutaj Południowy Służewiec, Śródmieście Zachodnie oraz obszar wzdłuż Alei Jerozolimskich, gdzie wchodzący do Polski kapitał zagraniczny i nowe firmy inwestowały w wiele nowych obiektów. Podobne zjawisko dotyczyło także w dużej mierze polskich prywatyzowanych przedsiębiorstw, m.in. z sektora finansowego.

\section{Analiza potencjału}

Wielkość przychodów przedsiębiorstw jest miarą syntetyczną i wskazuje na presję lub kierunki i centra natężenia siły ekonomicznej sektora działalności wytwórczej. Potencjał przychodów ważniejszych przedsiębiorstw obliczono według ilorazu: iloczynów przychodów (mln PLN) przez kwadraty odległości $(\mathrm{km})$ w kwadratowych polach $1 \times 1 \mathrm{~km}$. Ujawnione zostały interesujące zależności, przede wszystkim charakterystyczna była duża koncentracja potencjału na stosunkowo małym obszarze leżącym w większości w dzielnicy Sródmieście, a także częśsiowo na Woli i Ochocie (Ryc. 7).

Większe wartości potencjału charakteryzują obszar Południowego Służewca oraz wyginają się wzdłuż Alei Jerozolimskich. Wskazuje to na główne kierunki rozprzestrzeniania się siły ekonomicznej w układzie przestrzennym Warszawy i potwierdza uwagi zawarte w rozdz. 3 przy opisie rozmieszczenia siedzib.

Charakterystyczne jest duże zróżnicowanie rozmieszczenia obszarów największych wartościach potencjału w zależności od rodzaju sekcji. Najbardziej skoncentrowany charakter miały sekcje E i J, zaś najmniej - sekcja D. Wieloogniskowość potencjału przychodów w sekcji D związana była z siedzibami przedsiębiorstw tek kategorii: kilku podmiotów wchodzących w skład koncernu Deaewoo (ul. Jagiellońska) oraz grupy kilkudziesięciu różnych firm na Służewcu Południowym, z głównym centrum przy ul. Domaniewskiej. Dużo mniejsze wartości potencjału w przypadku analizowanej sekcji charakteryzowały obszar centrum Warszawy.

W przypadku sekcji J interesujący jest fakt położenia centrum potencjału na pograniczu dzielnic Śródmieście i Wola, co wynika z wcześniejszych uwag na temat rozmieszczenia siedzib przedsiębiorstw tej sekcji. Podobne przesunięcie - w stosunku do tradycyjnego śródmieścia, obszarów o najwyższych wartościach potencjału charakteryzuje także sekcje $\mathrm{K}, \mathrm{G}$ i F. 

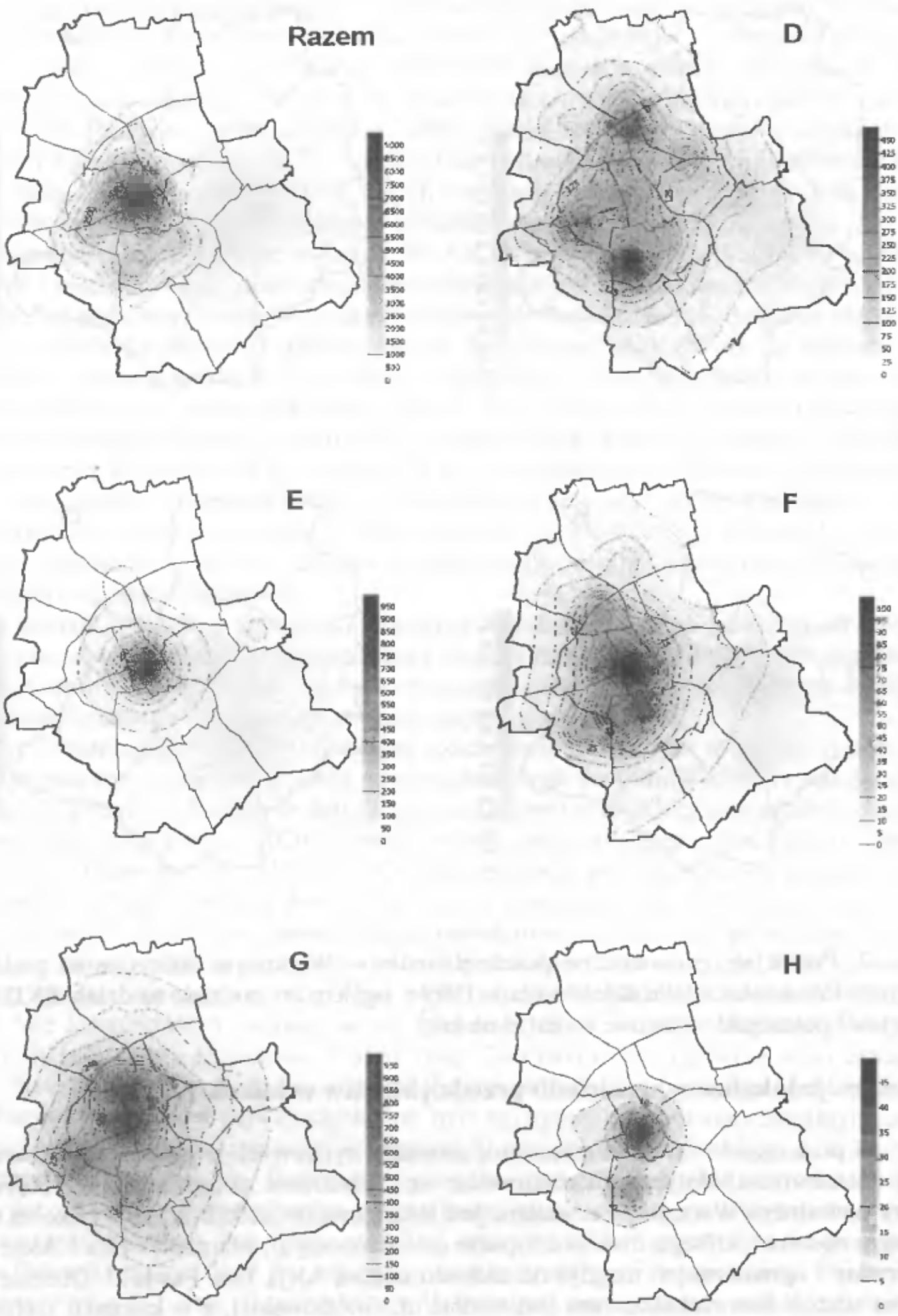

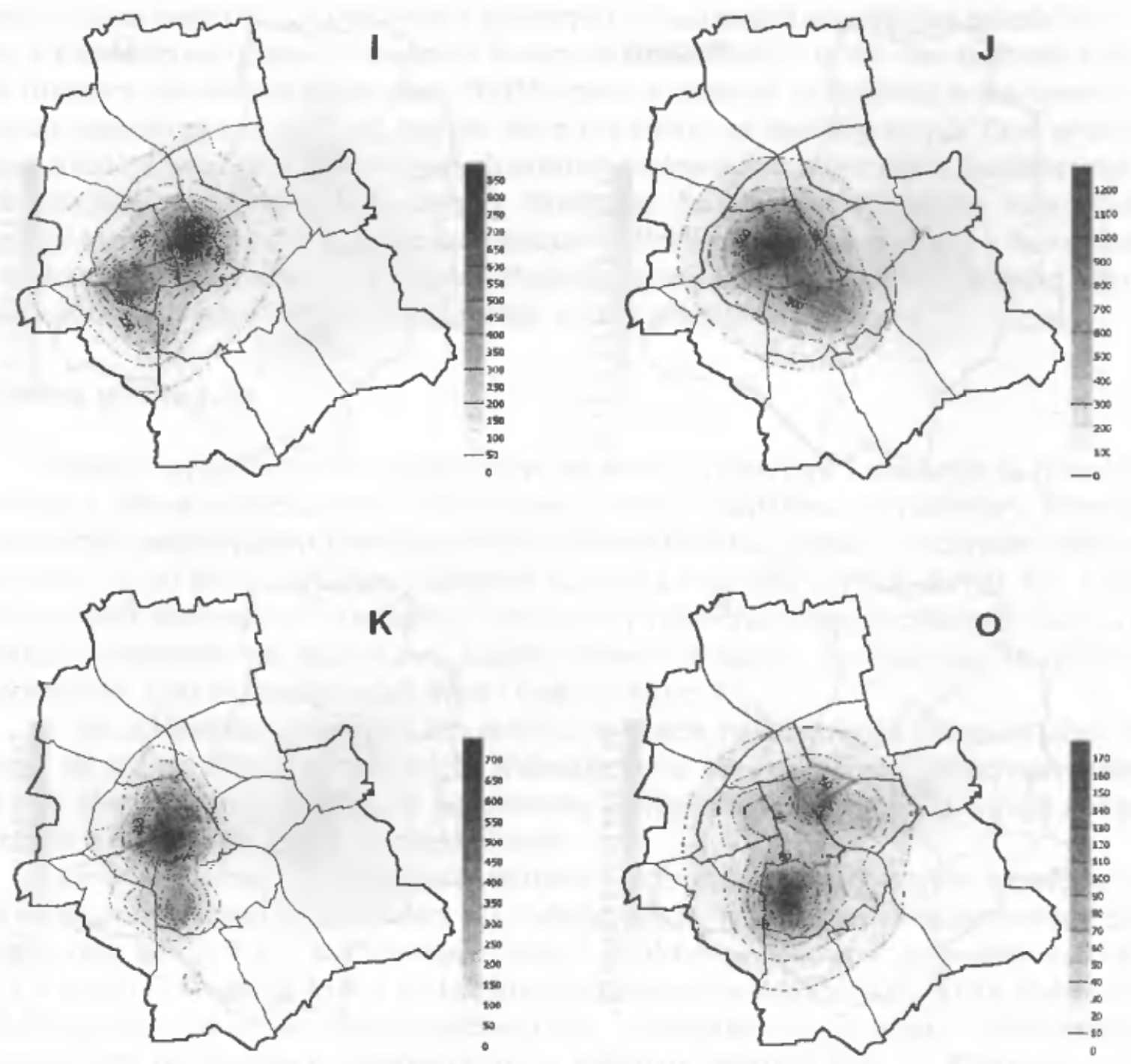

Ryc. 7. Potencjały ekonomiczne przedsiębiorstw w Warszawie obliczone na podstawie przychodów z całokształtu działalności w 1999 r. ogółem i w podziale na działy EKD. Wartości potencjału wyrażone w mln zł na km²

\section{Tendencje lokalizacyjne siedzib przedsiębiorstw w latach 1989-2000}

W przeciagu 10 lat od uruchomienia procesów rynkowych w polskiej gospodarce zaszły istotne zmiany dotyczące kształtowania się „przestrzeni zarządzania”. W obrębie obszaru centralnego Warszawy zauważalne jest lokalizowanie siedzib firm nie tylko na tradycyjnym obszarze, którego dwie prostopadłe osie stanowią ul. Marszałkowska i Aleje Jerozolimskie i ograniczonym niegdyś od zachodu obecną Aleją Jana Pawła II. Obecnie duża liczba siedzib firm zlokalizowana jest wzdłuż ul. Grzybowskiej, a w kierunku zachodnim od ul. Towarowej - przy ul. Kasprzaka. Dotyczy to w szczególności ośrodków zarządzania charakterystycznych dla sekcji J (pośrednictwo finansowe). 
W ciągu ostatnich 10 lat nastąpiło zatem wyraźne przesunięcie „centralnej dzielnicy interesów" w kierunku zachodnim i powstanie nowej osi jej rozwoju. Ze względu na dynamiczny rozwój inwestycji biurowych w centralnych obszarach miasta (zwłaszcza w ich zachodniej części), należy spodziewać się przemieszczeń wielu głównych siedzib, także w tym kierunku (np. na początku 2001 r. spółka Warta zasiedliła własny kompleks przy ul. Siennej 85/87, a w końcu 2001 r. spodziewane jest oddanie do uźytku biurowca PZU przy Rondzie ONZ). Równocześnie w innych częściach miasta powstają inne duże kompleksy biurowe, które także będą obiektem zainteresowania wielu firm.

Interesujące jest powstanie w latach $90 . \mathrm{XX}$ w. nowych skupisk siedzib firm. Największym i najciekawszym obszarem takiej koncentracji jest Południowy Służewiec, gdzie obserwuje się efektywne i efektowne zagospodarowanie dotychczasowej dzielnicy przemysłowej, co zostało szczegółowo opisane przez A. Rutkowską-Gurak (2000). Ze względu na swoją skalę i obecne moźliwości rozwoju, w nieodległej przyszłości będzie to zapewne główny konkurencyjny obszar lokalizacji siedzib firm dla „starego" centrum miejskiego. W latach 90. ubiegłego wieku powstał tam bowiem kompleks biurowy (Mokotów Business Park), w którym docelowo ma być ponad 250 tys. $\mathrm{m}^{2}$ powierzchni biurowej o standardzie A i B+. Inne mniejsze skupiska siedzib przedsiębiorstw powstały na Ochocie wzdłuż Alei Jerozolimskich, na Mokotowie przy ul. Pulawskiej oraz na Mokotowie i Wilanowie w okolicach ul. Sobieskiego. Są one również związane z nowowybudowanymi kompleksami biurowymi o wysokim standardzie.

W analizie wykazano, że centrum Warszawy związane jest silnie z funkcją zarządzającą. Innymi słowy stanowi ono bardzo ważny ośrodek decyzyjny. Można zatem uogólnić, że rozmieszczenie siedzib przedsiębiorstw, zwłaszcza dużych, wyznacza w dużym stopniu granice funkcjonalnego biznesowego centrum miejskiego (CBD).

Przez ostatnich 10 lat nastąpiło wyraźne rozszerzenie się centrum w kierunku zachodnim. Wytłumaczenia zjawiska wzrostu powierzchniowego centrum Warszawy należy doszukiwać się przede wszystkim w dotychczas stosunkowo niewielkiej powierzchni obszarów centralnych (Śleszyński 2002b). Centrum miasta socjalistycznego, choć bardzo ważne ideologicznie, ekonomicznie było słabe. Kierunek zachodni powiększania się centrum jest prawdopodobnie konsekwencją deindustrializacji i powstania dość rozległych obszarów poprzemysłowych, stosunkowo łatwych do zagospodarowania i przejęcia przez nowe funkcje. Dość istotne było także zainteresowanie władz lokalnych inwestycjami. Poza centrum głównym rejonem koncentracji siedzib był także Południowy Służewiec, a ponadto obszar wzdłuż Alei Jerozolimskich ciągnący się od dzielnicy Ochota do gminy Warszawa-Włochy oraz obszar północnego Mokotowa, wzdłuż ulicy Czerniakowskiej (głównie rejon urbanistyczny Sielce) i Alei Witosa, mający swe przedłużenie na zachodzie na Starym Mokotowie.

Wartość przychodów największych firm była najwyższa na obszarze centralnym, zaś w dalszej odległości koncentrowały się przychody przedsiębiorstw średnich, a w strefie zewnętrznej - najmniejszych. Można zatem uogólnić, że odległość siedziby od centrum miasta jest odwrotnie proporcjonalna od wielkości ekonomicznej przedsiębiorstwa (im większe przedsiębiorstwo, tym lokuje się bliżej centrum). W ten sposób rozkład przychodów na jednostkę powierzchni jest najwyższy na obszarach centralnych miasta. $Z$ powyźszego uogólnienia wynikają także implikacje dla mających zastosowanie modeli grawitacji. Rozkład potencjału ekonomicznego jest skoncentrowany na stosunkowo małym obszarze. 
Największą koncentracją rozmieszczenia siedzib charakteryzowała się sekcja J, najmniejszą - sekcje DE oraz K. Przyjęto zatem, że stopień koncentracji jest zależny od stopnia rozwoju działalności, w ten sposób, że lokalizacja siedzib podmiotów dla wysokorozwiniętych rodzajów działalności (m.in. usługi finansowe) ma bardziej skoncentrowany charakter, zaś dla podmiotów o niższym stopniu rozwoju (m.in. sektor przemysłowy) bardziej rozproszony. Ze sposobu rozmieszczenia siedzib przedsiębiorstw $w$ poszczególnych sekcjach wynika także zróżnicowanie rozkładu potencjału. Najbardziej skoncentrowany charakter miały sekcje E i J, zaś najmniej - sekcja D, gdzie zaobserowano wieloogniskowość rozkładu przestrzennego potencjału przychodów.

Różnice występowały także w rozkładzie siedzib przedsiębiorstw według ich struktury własnościowej. Państwowa przestrzeń zarządzania związana była przede wszystkim z dzielnicą Śródmieście. Własność prywatna i zagraniczna miała znaczny udział poza tradycyjnym obszarem centrum. Dowodzić to może dekoncentracji przestrzeni zarządzania po 1989 r. Wart podkreślenia i symboliczny jest także tak duży udział przychodów przedsiębiorstw kontrolowanych przez udziałowców zagranicznych poza tradycyjnym śródmieściem. Zmiany przestrzeni zarządzania w zależności od rodzaju własności będą następowały wraz z postępującą prywatyzacją przedsiębiorstw państwowych.

W przyszłości prawdopodobnie należy spodziewać się dwóch głównych procesów w obrębie kształtowania się przestrzeni zarządzania w Warszawie. Po pierwsze, będą następowały dalsze przemieszczenia siedzib przedsiębiorstw, związane $\mathrm{z}$ nowymi inwestycjami infrastrukturalnymi, a także wynikające ze spodziewanego napływu kapitału zagranicznego. Po drugie możliwa jest dalsza dekoncentracja przestrzeni zarządzania związana z powstaniem w ostatnich latach konkurencyjnych ośrodków poza tradycyjnym obszarem centrum.

Kształtowanie się „centralnej dzielnicy interesów” powinno mieć zatem wpływ na opracowania urbanistyczno-planistyczne dotyczące tego obszaru, także w skali całej Warszawy i jej aglomeracji. W obecnie obowiązujących lub przygotowywanych opracowaniach urbanistyczno-planistycznych granice centrum są jednak niedoszacowane. Analiza wskazuje wyraźnie na znaczne rozszerzanie się city miejskiego $(C B D)$ w stosunku do określonego w Studium uwarunkowań i kierunków zagospodarowania przestrzennego m.st. Warszawy przede wszystkim w kierunku zachodnim, a także południowym.

Autor $w 2002$ r. byl stypendysta Fundacji na rzecz Nauki Polskiej

\section{Literatura}

Borchert J.R., 1978, Major control points in American economic geography, Annals of the Association of American Geographers, 68, p. 214-232.

Burns L.S., 1977, The location of the headquaters of industrial companies: a comment, Urban Studies, 14, p. 211-214.

Chiba A., 1992, The locational changes of branch offices in Kagoshima City and their territories, Annals of the Japan Association of Economic Geographers, 38, p. 16-32.

Dicken P., 1977, A note of location theory and the large business enterprise, Area, 9, p. 138-143.

Dicken P., Lloyd P.E., 1978, Inner metropolitan industrial change, enterprise structure and study of external control and regional development, Regional Studies, 10, p. 181-197. 
Domański B., 1997, Geografia przedsiębiorstw - niedoceniany nurt badań w polskiej geografii ekonomicznej, [w:] Geografia - Człowiek - Gospodarka. Profesorowi Bronisławowi Kortusowi w 70. rocznice urodzin, Instytut Geografii UJ, Kraków, s. 101-112.

Eberhardt P., 1968, Wielkie miasta jako ośrodki koncentracji dzialalności gospodarczospolecinej w Polsce, Biuletyn KPZK PAN, 47.

Eberhardt P., Wróbel A., 1963, Regiony handlu hurtowego w Polsce, Przegląd Geograficzny, 35, s. 21-29.

Eberhardt P., 1970, Rola wielkich miast w strukturze regionalnej powiqzań przestrzennych $w$ Polsce, Biuletyn KPZK PAN, 58.

Eberhardt P., 1986, Rejonizacja przedsiębiorstw zaopatrzenia. dystrybucji $i$ handlu hurtowego w Polsce, Przegląd Geograficzny, 58, s. 703-733.

Evans A.W., 1973, The Location of the headquaters of industrial companies, Urban Studies, 10 , p. 387-395.

Fujita N., 1987. The location of the headquarters of large corporations in Japan, Annals of the Japan Association of Economic Geographers, 33 p. 45-46.

Funkcja adminïstracyjna miast, 1992, Acta Universitas Lodziensis, Folia Geographica, 17.

Goddard J.B., Smith I.J., 1978, Changes in corporate control in the Britain urban system, 1972-77, Environment and Planning A, 10, p. 1073-1084.

Goodwin W., 1965, The Management Center in the United States, Geographical Review, 55 , p. 1-16.

Guzik R., Gwosdz K., The Spatial concentration of concentration of control functions in Polish industry, [in:] Marszał T., Local economy and urban development in Poland, Department of the Built Environment and Spatial Policy University of Łódź, p. 52-61.

Hayter R., Watts H.D., 1984, The geography of enterprise: a reappraisal, Progress in $\mathrm{Hu}$ man Geography, 8, p. 157-181.

Hino M., 1995, The agglomeration of branch offices and their recent changes in major Japanese cities, Annals of the Japan Association of Economic Geographers, 42, p. 38-53.

Holloway S.R., Wheeler J.O., 1991, Corporate headquarters relocation and changes in metropolitan corporate dominance, 1980-1987, Economic Geography, 67, p. 54-74.

Kato Y., Yamazaki T., 1981, Changes in the office location of the CBD of Kobe, Annals of the Japan Association of Economic Geographers, 27, p. 15-32.

Liszewski S., Wolaniuk A., 1992, Wptyw funkcji administracyjnej na powstanie i rozwój Lodzi, Acta Universitas Lodziensis, Folia Geographica, 17, s. 121-136.

Malecki E.J., 1979, Locational trends in R\&D by large US corporations, 1965-77, Economic Geography, 55, p. 309-323.

Misztal S., 1998, Przeksztalcenia struktury przemystu Warszawy, Atlas Warszawy, 6, IGiPZ PAN, Warszawa.

McNee R.B., 1960, Towards a more humanistic economic geography: the geography of enterprise, Tijdschrift voor Economische en Sociale Geographie, 51, p. 201-205.

McNee R.B., 1958, Functional geography of the firm, with an illustrative case study from the petroleum industry, Economic Geography, 34, p. 321-337.

Nowosielska E., 2001, Wielkie firmy uslugowe w uktadzie nowych województw, [w:] Czyż T. (red.), Zróżnicowanie społeczno-gospodarcze w nowym układzie terytorialnym Polski, Biuletyn KPZK PAN, 197, s. 103-129. 
Owczarek J., 1983, Podziat terytorialny oddziahywania poszczególnych jednostek obrotu, Gospodarka Materialna, 6.

Pred A.R., 1974, Major job-providing organizations and systems in cities, Commission on College Geography, Resource Paper no. 27, Association of American Geographers, Washington D.C.

Pred A.R., 1977, City-Systems in Advanced Economies. Past Growth, Present Processes and Future Development Options, Hutchinson University Library, London.

Rees J., 1978, Manufacturing headquarters in a postindustrial context, Economic Geography, 54, p. 337-354.

Rutkowska-Gurak A., 2000, Miejski obszar przemyslowy jako środowisko lokalizacji firm (na przykładzie Służewca Przemysłowego), Monografie i Opracowania, 472, Szkoła Główna Handlowa, Warszawa.

Semple R.K., 1985, Quaternary place theory: An Introduction, Urban Geography, 6, p. 285-296.

Semple R.K., 1973, Recent trends in the spatial concentrations of corporate headquarters, 1955-1974, Economic Geography, 49, p. 309-318.

Semple R.K., Phipps A.G., 1982, The spatial evolution of corporate headquarters within an urban systems, Canadian Geographer, 25, p. 258-279.

Sheppard E., Maier G., Tödtling F., 1990, The geography of organizational control: Austria 1973-1981, Economic Geography 66, p. 1-21.

Śleszyńska M., Śleszyński P., 2001, Wielkie firmy i korporacje międzynarodowe; Banki, [w:] Atlas Świata - Encyklopedia Geograficzna Świata, t. 12, Agencja PublicystycznoWydawnicza Opress, Kraków, s. 138.

Śleszyński P., 2002a, Struktura i rozmieszczenie ośrodków zarzq̨dzania w polskiej gospodarce w 2000 r., Przegląd Geograficzny, 2, s. 199-228.

Śleszyński P., 2002b, Delimitacja centrum Warszawy - problemy badawcze, Prace Geograficzne, 184 , s. 65-102.

Śleszyński P., 2001a, Rozmieszczenie glównych siedzib ważniejszych przedsiębiorstw w Warszawie w 1999 r., [w:] XV Konwersatorium Wiedzy o Mieście, Katedra Geografii Miast i Turyzmu UŁ, Komisja Geografii Osadnictwa i Ludności PTG, Łódzkie Towarzystwo Naukowe, Łódź, s. 311-323.

Śleszyński P., 2001b, Lokalizacja glównych siedzib przedsiębiorstw w przestrzeni Warszawy w końcu lat 90., [w:] Czynniki i bariery regionalnej współpracy transgranicznej bilans dokonań, 50. Zjazd Polskiego Towarzystwa Geograficznego, Oddział Rzeszowski PTG, UMCS - Filia w Rzeszowie, Uniwersytet Rzeszowski, Rzeszów, s. 106-111.

Taylor M.J., Thrift N., 1981, Spatial variations in Australian enterprise: the case of large firms headquartered in Melbourne and Sydney, Environment and Planning A, 13, p. 137-146.

Westaway J., 1974, The Spatial hierarchy of business organizations and its implications for the British urban systems, Regional Studies, 8, p. 145-155.

Wheeler J.O., 1988, Spatial ownership links of major corporations: The Dallas and Pittsburgh examples, Economic Geography 64, p. 1-16.

Wheeler J.O., 1986, Corporate spatial links with financial institutions: The role of metropolitan hierarchy, Annals of the Association of American Geographers, 76, p. 262-274.

Wheeler J.O., Park S.O., 1984, External ownership and control: the impact of industrial organization on the regional economy, Geoforum, 15, p. 243-252. 
Wyżnikiewicz B., 1997, Regionalne zróżnicowanie sily ekonomicznej (na podstawie "Listy 500" największych przedsiębiorstw Gazety Bankowej), [w:] Gorzelak G. (red.), Przemiany polskiej przestrzeni, Studia Regionalne i Lokalne, 19 (52), Europejski Instytut Rozwoju Regionalnego i Lokalnego UW, s. 205-228.

Zeller Ch., 2000, Rescaling power relations between trade unions and corporate management in a globalising pharmaceutical industry: the case of the acquisition of Boehringer Manhaim by Hoffman - La Rouche, Environment and Planning A, 32, p. 1545-1567.

Zioło Z., 2001, Struktura branżowa $i$ koncentracja przestrzenna wiodacych światowych firm przemystowych, Prace Komisji Geografii Przemysłu Polskiego Towarzystwa Geograficznego, 3, s. 29-42.

Zioło Z., Piróg S., 2001, Koncentracja przestrzenna i struktura branżowa wiodacych firm zachodnioeuropejskich; [w:] 50 Zjazd Polskiego Towarzystwa Geograficznego: Czynniki i bariery regionalnej współpracy transgranicznej - bilans dokonań, Oddział Rzeszowski PTG, Uniwersytet Marii Curie-Skłodowskiej - Filia w Rzeszowie, Uniwersytet Rzeszowski, Rzeszów, s. 184-187. 